\title{
Regulation of Attorneys Under California's Talent Agencies Act: A Tautological Approach to Protecting Artists
}

\author{
James M. O’Brien III †
}

Lawyers increasingly play important and pervasive roles in the California-centered entertainment industry. When they step out of traditional legal roles to engage in agency or managerial ventures with their artist-clients, however, they risk breaching the licensing regulations of California's Talent Agencies Act. The Act, which is called into operation by the activity of "procuring, offering, promising, or attempting to procure employment or engagements for an artist," was designed to protect artists against iniquitous or overreaching conduct by their personal representatives. But unlike talent agents, personal managers, and other players in the industry, lawyers already answer to an ethical and legal code more rigorous than that of the Act. This Comment argues that the Act is at least redundant as applied to attorneys and potentially subjects them to penalties for tasks, made illicit when done for artist-clients, that they customarily perform for clients other than artists. Two alternatives to subjecting lawyers to the Act are proposed: the California legislature should substitute a registration requirement for attorneys in lieu of the Act's full-licensure requirements or, alternatively, reconsider its decision not to include an "incidental booking" exception within the Act. Either would help clarify the ambiguous scope of the Act and eliminate the dilemma that those lawyers who seek employment for their artist-clients might face. Absent such change, attorneys in California's entertainment industry are in an uncertain position-they constantly must beware of a statutory regime without knowing whether it actually applies to their conduct. And they can ignore the Act only at their peril.

$\dagger$ B.A. 1988, University of North Carolina, Chapel Hill; J.D. candidate 1992, Boalt Hall School of Law, University of California, Berkeley. I would like to thank Kirsten, who exhibited remarkable enthusiasm, affection, and restraint throughout the preparation of this Comment, Associate Dean and Professor of Law Edward L. Rubin for his comments on an earlier draft of this paper, and the staff of the California Law Review. 


\section{INTRODUCTION}

Over the past century, California has become a dominant force in the entertainment imdustry. ${ }^{1}$ California's success in this business is due, in part, to the efforts and interaction of an assortment of artists and artists' representatives including talent agents, personal managers, promoters, business managers, accountants, and attorneys. ${ }^{2}$ Of these representatives, perhaps none plays a more pervasive role than the lawyer. ${ }^{3}$

Unlike artists' other personal representatives, attorneys participate in all aspects of the entertainment industry, from representing artists and other creative personnel in their personal and busmess affairs to representing motion picture studios, record companies, and distribution entities in their corporate or coinmercial endeavors. In representing their artist chents, attorneys may provide purely legal services or may serve in extralegal capacities by functioning as talent agents or personal managers. ${ }^{4}$ Passage of attorneys into these less customary roles can occur intentionally ${ }^{5}$ or, as is more often the case, madvertently. ${ }^{6}$ The attorney who engages in agency or managerial ventures, however, risks breaching the hicensing regulations of California's Talent Agencies Act (the Act), ${ }^{7}$ a

1. For pnrposes of this Comment, the term "entertainment industry" refers to all species of entertainment and subsidiary businesses, including music, video, television, motion pictures, and radio. Florida, Nashville, and New York are also significant bases of entertainment-industry activity.

2. The artist's advisors and consultants are known collectively as "personal representatives." Luaine L. Quast, Musicians, Their Representatives, and the Agreements Between Them, in 1990 Entertainment, Publishing aNd the ARTs Handbook 191, 191 (John D. Viera \& Robert Thorne eds.).

3. For a more detailed description of the entertainment attorney's role, see infra text accompanying notes $69-84$.

4. See Donna G. Cole-Wallen, Cominent, Crossing the Line: Issues Facing Entertainment Attorneys Engaged in Related Secondary Occupations, 8 HASTINGs CoMM. \& ENT. L.J. 481, 482 (1986) ("The popularity of entertainment law has incvitably led many entertainment attorneys to enter into non-legal activities and to perform roles beyond traditional legal representation.").

5. Cole-Wallen states: "The complexity of contract negotiation [in the entertainment industry] may lead the attorney to believe that the talent agent and personal manager are inadequate for the job. Thus, the attorney may expand his role and eliminate the need for other representatives." Id. at 492-93.

6. Cole-Wallen states: "The managerial function of advising and counseling artists in their careers ... [is] inextricably bound with probleins of law and contracts. Sometimes attomeys gravitate into the managerial functions because there are gray areas between legal advice (the attorney's function) and career advice (the personal manager's function)." Id. at 493 (footnote omitted). In the music business, for instance,

attorneys hold positions of great power ... . Part of this power has come about by default.

In the earlier years of the business, most executives, agents and managers laeked the education and background to run big companies and handle the affairs of millionaire clients. Even today, executives lacking strong backgrounds in business management and business law keep their lawyers close at hand to protect them against unwise deeisions and flawed contracts.

David Baskerville, Music Business Handbook and Career Guide 158 (3d ed. 1982).

7. CAL. LAB. CODE $\S \S 1700-1700.47$ (West 1989 \& Supp. 1991); see also Cole-Wallen, supra 
statute designed to protect artists against iniquitous or overreaching conduct by certain personal representatives.

Specifically, it is the activity of "procuring, offering, promising, or attempting to procure einployment or engagements for an artist"8 that calls the Act into operation. ${ }^{9}$ Under prevailing interpretations, attorneys who engage in such procurement activities for their artist-clientswhetlier inadvertently or intentionally-are subject to the Act's requirements and penalties. ${ }^{10}$ Unfortunately, few practitioners in the entertainment industry are aware of these expansive interpretations of the Act; and inost practitioners fail to recognize that their status as attorneys miglit not insulate thein from the Act's regulations. ${ }^{11}$

Attorneys who register with the California Labor Commissioner as talent agents expose themselves to the various financial, documentary,

note 4, at 516-17 n.189 ("[S]ince the Labor Commission feels that attorneys are subject to licensing under the Act, attorneys probably are subject to penalties for violating the provisions of the Act.").

8. CAL. LAB. CODE $§ 1700.4$ (a) (West 1989).

9. Id. $\$ \S 1700.4 .5$ (West 1989 \& Snpp. 1991) (persons without a license from the Labor Commissioner are prohibited from "procuring, offering, promising, or attempting to procure employment" for artists). The absence of any definition of "procurement" is one of the Act's greatest sliortcomings, and generates great confusion among practitioners, artists, and lawmakers. For a more detailed discussion, see infra Section III.B.

10. See supra note 7; see also The Licensing and Regulation of Artists Managers, Personal Managers, and Musicians Booking Agencies: Hearings Before the California Legislature Senate Comm. on Industrial Relations 222 (1975) [heremafter Hearings] (testimony of Marilyn Lazar, Referee, Labor Commission, Los Angeles) ("When attorneys act as an artists' [sic] manager [now called talent agent], they must be licensed ... ."); REPORT of THE CALIFORNIA ENTERTAINMENT COMmission to THE Governor AND Legislature 6 (1985) [hereinafter ENTERTAINMENT COMmission REPORT] (submitted pursuant to Act of Aug. 31, 1982, ch. 682, sec. 6, $1982 \mathrm{Cal}$. Stat. 2814, 2816, repealed by Act of July 17, 1984, cl. 553, 1984 Cal. Stat. 2185 (effeetive Jan. 1, I986)) ("[A]nyone not licensed as a talent agent slould not, under any condition or circumstances, be allowed to procure employment for an artist ...."); Richard L. Feller, California's Revised Talent Agencies Act: Fine-Tuning the Regulation of Employment Procurement in the Entertainment Industry, ENT. \& SPORTS LAw., Fall 1986, at 3, 3 ("[T]he Act does not exempt attorneys from its coverage when acting as legal counsel."); Martin D. Simger, Regulation of Talent Agents: The Richard Pryor Determination, in 1983 ENTERTAINMENT, PUBlishING AND THE ARTS HANDBOOK 255, 255 (Miclıal Meyer \& John D. Viera eds.) [heremafter 1983 HANDBooK] ("[E]ven if an individual claims to act as a personal manager, business manager, attorney, joint venturer, or officer of a loan-out company for an artist, it will not prevent the California Labor Commissioner from resolving claims that are made against that individual by the artist . . . " (emphasis added)); ColeWallen, supra note 4, at 517 ("[I]t is likely that California attorneys will be subjeet to the licensing requirements of the Talent Agency [sic] Act if they perforn procurement services for an artist."); Interview with H. Thomas Cadell, Clief Counsel, State of California Department of Industrial Relations, Division of Labor Standards Enforcement, in San Francisco, Cal. (Mar. 8, 1991) (stating that if an attorney liceused to practice in the State of California procures or attempts to procure employment for an entertainment client, lie would be subject to penalties for acting contrary to the Act). Altliougl there is no specific statutory language in the Act that expressly governs personal managers or attorneys, they seem to be regulated inferentially by virtue of the Act's definition of "talent agent." See Cal. LAB. Code § 1700.4(a) (West 1989).

11. Cole-Wallen, supra note 4, at 512 (citing Hearings, supra note 10, at 222). Infornal conversations between the author and numerous practitioners in the entertainment industry also sustain this contention. 
and bureaucratic burdens the Act imposes. If attorneys remain unlicensed, the Act effectively prohibits them from performing tasks-such as contract negotiations-that are customarily associated with and executed by attorneys; consequently, lawyers not licensed under the Act are potentially vulnerable to the Labor Commissioner's broad authority to grant relief against unlicensed talent agents.

The consequences of actimg as an unlicensed talent agent can be disastrous. Anyone who purposely solicits engagements for an artist-client or inadvertently crosses the line into regulated activity faces harsh penalties, including forfeiture of commissions, repayment of past fees, loss of future earnings, and invalidation of management and collateral agreements. ${ }^{12}$ In Pryor v. Franklin, ${ }^{13}$ for exainple, comedian/actor Ricliard Pryor brought an action under the Act agamst his personal representative, David Franklin. Over a period of years, Franklin had purportedly acted as Pryor's personal manager, attorney, and loan-out corporation officer, and had procured employment for Pryor and conducted his otler business affairs. ${ }^{14}$ Franklin challenged Pryor's claim, arguing that he had not violated the Act because he procured employment for Pryor in his capacities as attorney and officer of Pryor's loan-out company, not as a talent agent. ${ }^{15}$ Franklin challenged the Labor Commissioner's jurisdiction on the same grounds. ${ }^{16}$ The Labor Commissioner summarily rejected Franklin's contentions, holding that the Commissioner has the power and duty to " "search out illegality lying behind the form in which a transaction has been cast for the purpose of concealing such illegality." "17 Pursuant to that autlority, the Commissioner found that Franklin's cliaracterization of his procurement services as those of a lawyer rather than a talent agent constituted "blatant subterfuge" since Franklin was not licensed to practice law in Califorma. ${ }^{18}$ In short, Franklin lost because le procured employment for Pryor without first obtaining a talent agency license. And his attorney defense was rejected because lie was not licensed to practice law in California. For these and other reasons, the Labor Commissioner granted Pryor an award exceeding $\$ 3,000,000$. $^{19}$

12. See infra text accompanying notes $123-28$.

13. No. TAC 17 MP 114 (Cal. Labor Comm'r 1982), discussed in Singer, supra note 10, at 256-57.

14. Singer, supra note 10 , at $256-57$.

15. Id. at 257 .

16. Id. at 256 .

17. Id. (quoting Pryor, No. TAC 17 MP 114, at 17).

18. Id.; see id. at 261-62 n.7 (citing to evidence at the hearing that Franklin was licensed to practice only in the District of Columbia, not California).

19. Donald E. Biederman et al., Law and Business of the Entertainment INDUSTRIES 491 (1987). While the final resolution in Pryor (and the large award against Franklin) rested in large part on Franklin's fraudulent activity and breach of fiduciary duty, id. at 491-93 
More recently, talk show host Arsenio Hall instituted a Labor Con1nission proceeding against his former representative, Robert Wachs. ${ }^{20}$ Hall is seeking to force Wachs, who is also an attorney, personal nianager, and owner of a nianagenient conipany, to return all fees and con1nissions-reportedly totalling almost $\$ 8,000,000^{21}$ - on the grounds that Wachs violated the Act by procuring eniployment for Hall without a talent-agency license. ${ }^{22}$ If the Labor Commissioner follows Pryor and finds that Wachs performed procurenent activities without a talentagency license, Wachs could be conpelled to return those fees and commissions.

Although the question of whether attorneys who partake in procurenent activities for artist-chents have violated the Act arose during legislative hearings niore than fifteen years ago, ${ }^{23}$ the issue has yet to be directly addressed by the Labor Commissioner, ${ }^{24}$ and the subject has generated considerable confusion among practitioners in the business for years. ${ }^{25}$ Concededly, neither Pryor nor the Arsenio Hall proceeding directly examines the question, and the Labor Commissioner's failure to discuss it invites arguinents that the problen is inore illusory than real. Nevertheless, the cases do suggest that attorneys who engage in procurement activity for their artist-chents nust be wary of the Act's proscriptions and penalties. And although it has not been conclusively established that attorneys who procure eniploynient for artists fall within the scope of the Act, Pryor and the Hall proceeding mdicate that such a scenario is certainly foreseeable. ${ }^{26}$ Given current Labor Commissioner interpretations of the Act, which correlate certain functions traditionally

(analyzing Pryor, No. TAC 17 MP 114), the case is significant primarily because it acknowledges the issue of whether the Act applies to attorneys, rejects Franklin's attorney defense, and perpetuates the confusion on the issue of the Act's applicability to attorneys hicensed to practice law in California.

20. Lauren Blau, Former Arsenio Hall Manager Challenges Talent Agencies Act, L.A. DAILY J., Jan. 14, 1991, at 3.

21. Id.

22. Id.

23. See Hearings, supra note 10, at 9-10 (testimony of Marvin Faris, then-President of Artists' Managers Guild, stating that while the original intention of the Act may have becn only to control talent agents, it is presently unclear who is covered), 43 (testimony of Roger Davis, then-Vice President of Artists' Managers Guild, coimnenting that attomeys were not ineant to be covered because the state bar was too strong and such regulation would be duphicative).

24. Singer, supra note 10, at 257 ("One of the issues that has not yet been decided . . . is whether an attorney who is licensed to practice law in California would be in violation of the Talent Agencies Act if he or she were to procure employment for his or her artist/client.").

25. See Cole-Wallen, supra note 4, at 514 (confusion exists as to whether personal representatives other than talent agents are subject to the Act's regulations).

26. See Hearings, supra note 10, at A-25. Walter L.M. Lorimer, an attomey who participated in drafting the Artists' Managers Bill in 1959, asserted that even an opinion by the State's Legislative Counsel that attorneys were not covered by the Act would not prevent an artist from suing his attorney to recover fees paid if the lawyer had, in the course of rendering legal serviees, also assisted the artist in obtaining employment. Id. 
performed by attorneys to unlawful procurement activity, ${ }^{27}$ it is simply a matter of time before an artist seizes on the theory of attorney liability under the Act in order to recover fees and commissions from a lawyer who disregarded or was unimformed about the Act's potentially broad scope.

This Comment explores the Act's apphicability to attorneys who procure employinent for artist-clients, arguing that the Act should be amended to remedy an important shortcoming: the Act's failure to exeinpt attorneys from its operation, particularly when they do no more than perform tasks traditionally associated with the practice of law. This Comment is also nitended as a tacit admonition to lawyers in the entertainment industry who seek or procure employment for artist-clients to be aware of-and wary of - the Act; any entertainment-industry attorney actively engaged in the representation of artists who is ignorant of the Act and its potential operation risks defending an action initiated by an artist seeking to recover fees and commissions by charging that the lawyer acted as an unlicensed talent agent. Conversely, the artist might attempt to use the Act as a shield aganist an attorney who has instituted a proceeding against the artist to collect fees or conimissions. In such a situation the artist could defend by arguing that the attorney is entitled to no fees because he acted as an unlicensed talent agent. ${ }^{28}$

Part I of this Comment introduces various entertainment-industry players, delineates their roles, and explains the conphicated, interlocking web of relationships that they establish. The discussion reveals the difficulties the legislature and the participants theniselves have had in attenupting to classify the activities of the various players into bright-line categories for purposes of remedial legislation such as the Talent Agencies Act.

Part II probes the inechanics of the Act. It acknowledges the Labor Coinmissioner's original jurisdiction, explains the Act's application and bond requireinents, and examines its regulation of business practices. This Part also describes procedures before the Labor Coninissioner and analyzes the Commissioner's extremely broad authority to enforce the Act and fashion reniedies.

Part III advocates an express exeniption from the licensure requireinents of the Act for attorneys. This Part first exaninies the Act's purposes and legislative history, arguing that it never purported to apply to the activities of attorneys and that prevailing interpretations have for-

27. See infra text accompanying notes 171-77.

28. This scenario, of course, assumes that either the attorney initially brought the action before the Labor Commissioner or the artist successfully argued that the action fell within the Labor Commissioner's original jurisdiction over disputes between artists and talent agents per Section 1700.44(a) of the California Labor Code. See infra Section II.A. 
saken original intent, effectively casting the Act's net too widely. Second, it argues that the Act's ambiguous language-especially its rehance on the term procurement-unfairly subjects attorneys to the Act's proscriptions by equating tasks customarily performed by attorneys to illicit conduct and by giving madequate warning of what activity constitutes procurement. Third, and perhaps most importantly, this Part contends that the Act is redundant as applied to attorneys, wlio are already governed by the Rules of Professional Conduct of the State Bar of Califorma ${ }^{29}$ (heremafter Professional Rules) and the State Bar Act. ${ }^{30}$ In light of these regulations, Part III concludes that members of the Cahfornia Bar should be exempted from the requirenents of the Act.

This last argument is predicated on the tautological and occasionally contradictory nature of the Act's requirements in light of California's legal-ethics code. The Professional Rules and State Bar Act, specifically drafted for lawyers, are more rigorous than the requirements of the Act and adequately secure the Act's professed goal: protection of artists from unscrupulous personal representatives. The Act is therefore redundant as apphed to lawyers. Even when attorneys don more than one hat and act as attorney-managers or attorney-agents, artists are protected by the requirement that attorneys always conduct themselves according to the ethical and legal constraints imposed on them as attorneys. Moreover, several of the Act's requirements are in direct conflict with the Professional Rules. Simply stated, there is no clearly expressed policy or pragmatic basis for attorney licensure under the Act in liglit of Califorma's legal-ethics rules.

Part IV proposes two alternatives to express exemption of attorneys. The first alternative invites the Califorma Legislature to substitute a registration requirement for attorneys in heu of the Act's current fulllicensure requirements. The second alteruative recommends that the California Legislature reconsider its decision not to include an "mcidental booking" exemption in the Act. Such an exception-specifically tailored to exclude lawyers from the Act when procurement activity is not their primary function-would further clarify tlie intended scope of the Act and would eliminate the dilemma that currently faces those lawyers who only periodically or imcidentally seek employment for their artistchients.

29. Cal. Civ. \& Crim. Rules, Rules of Professional Conduct of the State Bar of California Rules 1-100 to 5-320 (West Supp. 1990) [hereinafter Professional Rules].

30. CAL. Bus. \& Prof. CODE $\S \S 6000-6228$ (West 1990 \& Supp. 1991). 


\section{I}

\section{Players in the California Entertainment INDUSTRY ${ }^{31}$}

Much of the confusion surrounding the Talent Agencies Act stems from the inherent imprecision with which the roles and diverse activities of the various entertainment-industry participants are dehineated. ${ }^{32}$ The functions of the assorted personal representatives are indistinct, overlapping, and often misunderstood, inaking bright-line classifications for legislative purposes difficult. In order to dispel some of these misconceptions, unravel the intricate tangle of relationships, and facilitate further discussion of the central issues of this Comment, descriptions of the more important representatives and their roles are set out below. ${ }^{33}$

\section{A. $\quad$ Talent Agents ${ }^{34}$}

The talent agent's primary function is to market the artist's talent to buyers within the entertainment mdustry. ${ }^{35}$ After locating such purchas-

31. Readers well-versed in the activities, purposes, and functions of artists' personal representatives, and conversant in the operation of the entertainment industry, should proceed to Part II.

32. Cf. Cole-Wallen, supra note 4 , at 528 (stating that one problem confronting personal representatives is the indefinite nature of their functions and the tendency of the services they render artists to overlap).

33. Artists are broadly defined in the Act:

"Artists" means actors and actresses rendering services on the legitimate stage and in the production of motion pictures, radio artists, musical artists, musical organizations, directors of legitimate stage, motion picture and radio productions, musical directors, writers, cinematographers, composers, lyricists, arrangers, models, and other artists and persons rendering professional services im motion picture, theatrical, radio, television and other entertainment enterprises.

CAL. LAB. CODE § 1700.4(b) (West 1989). This definition does not include athletes, who are dealt with separately in another chapter of the Labor Code. See id. $\S \S 1500-1547$ (West 1989) (the Athlete Agents Act).

Fortunately, little controversy has surrounded this statutory definition, making artists the most readily identifiable class in the industry. In legal conteinplation, artists become the principals in a principal-agent relationship with their internediaries; the personal representative is the agent (employee) of the artist (employer), and agency law is applicable. 1 JosepH TAUBMAN, Performing ARTs MANagement and Law § 2.7, at 45 (1972); Quast, supra note 2, at 202.

34. Talent agents are known by many names, including bookers, managers, or artists' managers. BASKERVILLE, supra note 6, at 150. Older versions of the Talent Agencies Act used the epithet "artists' manager." In fact, the Act itself, until 1978, was entitled the Artists' Managers Act. For pnrposes of this Comment, however, and in keeping with the modern phraseology adopted by the Act, the designation "talent agent" will be used.

35. BASKERVIIIE, supra note 6, at 150; BIEDERMAN, supra note 19, at 473; Quast, supra note 2, at 192; Adam B. Nimoy, Comment, Personal Managers and the California Talent Agencies Act: For Whom the Bill Toils, 2 Loy. L.A. ENT. L.J. 145, 147 (1982); Howard L. Thaler, Personal Managers-Their Legal Status and Problems 2 (1979) (paper presented at the Current Legal Trends and Developments in the Entertainment \& Sports Industries Forum, Los Angeles, Cal., Mar. 9-10, 1979).

The enterprise of a talent agent or talent agency is described in the Talent Agencies Act. Section 1700.4(a) provides: 
ers, talent agents often negotiate the particulars of employment. They might also counsel and advise artists in the development of their careers, although talent agents are under no statutory obligation to do so. ${ }^{36}$

The service a talent agent renders contemplates two types of chients: sellers and buyers of talent. ${ }^{37}$ While the mainstay of the talent agent's clientele is his or her roster of artists (the sellers),

[h] is other kind of client is the buyer of such talent-producers, record companies, publishers, packagers, promoters and club owners. [The talent agent's] job is to dehiver his artists to talent buyers. He serves as the middle man, the negotiator. He knows, or should know, what an artist is wortll, and he must know what the buyer is willing and able to pay. ${ }^{38}$

The talent agent might even act in an entrepreneurial capacity, periodically securing employment for artist-chents in performances or productions of the agency's own design.

Exclusivity is a prominent concept in show-business relationships, and agency agreements between artists and talent agents typically mcorporate a clause estabhishing this aspect of the affiliation. ${ }^{39}$ Because talent agents often view their representations of artists as risky imvestments, they inay negotiate exclusive rights to represent those artists in the widest geographical territory possible. ${ }^{40}$ In addition, agents endeavor to extend their representation of artists to all modes of entertainment within the industry. ${ }^{41}$ By doing so, talent agents effectively lock themselves into a portion of any compensation received by artists, regardless of the inedia, product, or location.

As remuneration for their efforts, talent agents customarily collect fees in the ainount of $10 \%$ of an artist's gross earnings-hence the appel-

\footnotetext{
"Talent agency" ineans a person or corporation who engages in the occupation of procuring, offering, promising, or attempting to procure employinent or engageinents for an artist or artists, except that the activities of procuring, offering, or promising to procure recording contracts for an artist or artists shall not of itself subject a person or corporation to regulation and licensing under this clrapter. Talent agencies may, in addition, counsel or direet artists in the developinent of their professional careers.
}

CAI. LAB. CODE § 1700.4(a) (West 1989).

Talent agents may operate independently, but generally they practice "within the confines of a large or mediun-sized agency." Cole-Wallen, supra note 4, at 489 . Two well-known agencies are International Creative Management (ICM) and The William Morris Agency, Inc. See id. at 489 n.48.

36. See CaL. LaB. CoDE $\S 1700.4$ (a) (West 1989) (talent agents "may ... counsel or direct artists in the development of their professional careers" (emplrasis added)).

37. BASKERVILLE, supra note 6 , at 150 .

38. Id.

39. Quast, supra note 2, at 202-03 (asserting that "exclusivity is a central part of every industry relationslip").

40. Id. at 203.

41. See id. Quast explains that in agency contracts between talent agents and inusicians the talent agent "may wish to represent the inusician should the musician do a movie, or write a book, or do a television advertisement for Pepsi-Cola, or engage in artistic endeavors as yet unforeseen and unknown." Id. 
lation "tenpercentery"-although commissions of $15 \%$ or $20 \%$ may be negotiated for certain types of engagements. ${ }^{42}$ Although there is no law establishing a ceiling on the fees a talent agent may charge, California Labor Commission policy limits the agent's commission to $25 \% .^{43}$ The rate is usually furtlier limited to $10 \%$ or $20 \%$ by the various entertainment unions and guilds. ${ }^{44}$

In spite of the importance of talent agents, unproven artists are seldom able to secure the services of a reputable agent. In fact, "many performers have found that the [talent] agency will ordinarily not get mvolved unless it anticipates possibilities of economic return. The result is that a neophyte often lias great difficulty in being sigued up by a [talent] agency unless the performer has attained celebrity or near-celebrity status." 45

Talent agents in the State of Califorma must be licensed. ${ }^{46}$ Califorma's laws governing agents evolved in response to unscrupulous practices of vaudeville agents who occasionally sent artists to dangerous or unhealtliy locations, sent minors to places where alcohol was sold and consumed, or split fees with owners or managers of the various venues that booked the artists. ${ }^{47}$

42. Joseph Taubman, IN Tune With the Music Business 84 (1980); see also BASKERVILLE, supra note 6, at 151 (agencies may charge commissions of ten to twenty percent of gross earnings); 3 Alexander Lindey, Lindey on ENTERTainment, Publishing and the ARTS $\S 14: A(3)$ (2d ed. 1990) (same).

43. Staff of the Cal. Senate Comm. on Business and Professions, 1982 Regular SESS., STAFF ANALYSIS OF ASSEMBLy BILL 997, at 1 (1982) [heremafter STAFF ANALYSIS]; see also Cole-Wallen, supra note 4 , at 521 n.218.

44. STAFF ANAL ysis, supra note 43, at 1; Cole-Wallen, supra note 4, at 520-21 (explaining that there is no California law setting a limit on talent-agency fees, but that the various entertainment umions impose "fee ceilings" for talent agents).

45. TAubman, supra note 42, at 85; see also Quast, supra note 2, at 191 (the unestablished artist rarely gets an agent because "[i]t is easier for an agent to sell a big name than to sell many small ones"), 203 (a talent agent "will take the risk of investing in an artist [only] if the artist will help insure his prosperity"). The tendency of talent agents to forgo representing as-yet-unprofitable artists can be explained by the notion that ten percent of nothing is still nothing.

46. CAL. LAB. CODE $\S 1700.5$ (West Supp. 1991) ("No person shall engage in or carry on the occupation of a talent agency without first procuring a license therefor from the Labor Commissioner.").

47. Quast, supra note 2, at 193 . While the rationale for restricting an agent's ability to send artists to unhealthy or unsafe locations or to send minors to bars and saloons is relatively selfevident, further explication of "fee splitting" may be essential to expose its iniquitous underpinnings and to justify its prolibition. Fee splitting is a practice whereby an agent or other personal representative agrees to pay one or more employers of talent (for exainple, nightclub owners) certain sums in exchange for the employer's promise not to lire any artists except those represented by the agent. Hearings, supra note 10, at A-6 (statement of Walter L.M. Lorimer). The agent then books lis artists into the employer's venue, collects a commission from the artists as compensation for the agent's procurement of employment for the artist, and turns over part of the commission to the einployer (in this case, the club owner). Id.

For example, assume that an artist is to be paid $\$ 1,000$ for a performance, that the agent charges a commission of $15 \%$, and that the agent then turns over a portion of that commission (say, 
In addition to state licensing requirements, talent agents are subject to regulations proinulgated by the various entertainment unions. Unions not only dictate limits on fees; they also require tliat form contracts be utilized, that fees be surrendered if an artist nets less than a minimum wage from a particular engagement, and that the agent obtam a franchise license. ${ }^{48}$ Without a franchise license fronı a particular union, a talent agent cannot procure einployment for any meinbers of that union. ${ }^{49}$

\section{B. Personal Managers}

Artists typically engage personal managers im addition to talent agents. In fact, a personal manager is often the artist's first representative because niany unseasoned artists lack business savvy, legal sophistication, and contacts in the business, and because agents of any consequence rarely accommodate fledgling artists. ${ }^{50}$ Managers of sucl mexperienced artists often suggest that their extensive contacts and expertise in the industry will enhance the artist's opportumity for eventual success; a manager might even imply that with personal guidance an artist will ultimately achieve stardom. ${ }^{51}$ Soon after establishing a rapport with the artist, the personal manager will custoinarily execute a manage-

$5 \%$ ) to the club owner. See id. The artist nets only $\$ 850$, the agent takes $\$ 100$ and the club owner receives $\$ 50$. Such arrangements have several detrimental effects on artists. First, the club owner's $\$ 50$ share is taken out of the artist's pocket; in effect, it is a double commission. Second, fee sphitting has the consequence of monopolizing a segment of the inarket by blocking out artists who are not represented by or who are unwilling to pay off the agent involved. Id. Finally, if an employer wishes to hire an artist who is not represented by the agent who has inade fee-sphitting arrangements, the employer inust inform the artist that he can only be hired through the agent; then the artist inust inake arrangements to pay the agent a commission even though the artist has had no previous contact with the agent and the agent has rendered no services to the artist. Id. at A-6 to A-7.

48. Quast, supra note 2, at 197.

49. Cole-Wallen, supra note 4 , at 519 .

50. See 3 LINDEY, supra note $42, \S 14: \mathrm{D}(2)$; supra note 45 and accoinpanying text; see also Quast, supra note 2, at 191 ("Usually the single person a budding musician hires, if he can afford to hire anyone, is a personal manager.").

51. 3 LiNDEY, supra note $42, \S 14: \mathrm{D}(2)$. This notion of the personal manager as self-styled "starmaker" is clearly depicted in the lyries of the Pink Floyd song Have a Cigar:

Come in here, dear boy, have a cigar. You're gonna go far, fly high,

You're never gonna die, you're gonna inake it if you try; they're gonna love you.

Well I've always had a deep respect, and I inean that most sincerely.

The band is just fantastic, that is really what $I$ think. Oh by the way which one's Pink?

And did we tell you the name of the game, boy, we call it Riding the Gravy Train.

We're just knocked out. We heard about the sell out. You gotta get an album out, You owe it to the people. We're so happy we ean hardly count.

Everybody else is just green, have you seen the chart?

It's a helluva start, it could be inade into a monster if we all pull together as a team.

And did we tell you the name of the game, boy, we call it Riding the Gravy Train.

Roger Waters, Have a Cigar, on Wish You Were Here (Columbia Records 1975). The song alludes to a situation early in the band's career in which a candidate for managenent, promising the band imminent faine, asked the band members, "Which one is Pink?" KaRL Dallas, BRICKS IN THE WALL 22 (1987). 
ment contract with the artist that, not surprisingly, emphasizes the manager's interests. ${ }^{52}$ Such agreements generally contain an exclusivity clause similar to that found in the artist-agent contract. ${ }^{53}$

The manageinent agreement ordinarily includes an array of provisions equivocally delineating the personal manager's obligations to the artist. ${ }^{54}$ In essence, "the primary function of the personal manager is that of advising, counselling, directing and coordinating the artist in the developinent of the artist's career." 55 The manager's task encompasses matters of both business and personal significance. As business advisors, they might attend to the artist's finances, ${ }^{56}$ and they routinely organize the economic elements of the artist's personal and creative life necessary to bring the chent's product to fruition. ${ }^{57}$ The personal inanager frequently lends money to the neophyte artist, thereby speculating on a return from the artist's anticipated future earnings. ${ }^{58}$ The manager also serves as a haison between the artist and other personal representatives, arranging their interactions with, and transactions on behalf of, the artist. On a more personal level, the manager often serves as the artist's confidant and alter ego. ${ }^{59}$ The manager might nurture the artist's personal relationships, ${ }^{60}$ mollify the artist's bruised ego, endure telephone

52. 3 LiNDEY, supra note $42, \S 14: \mathrm{D}(2)$.

53. See supra text accompanying notes $39-41$ (discussing the artist/agent relationship). For examples of personal management agreements, see 3 LINDEY, supra note 42, § 14:D-2.01; Thaler, supra note 35 , app. at 1-5.

54. See Quast, supra note 2, at 207. Commonly offered services include:

(1) Advice and counsel in the selection of literary, artistic, and musical material.

(2) Advice and counsel in publicity, public relations, and advertising.

(3) Advice and counsel in choosing a proper format to showcase the artist's talents

and in determining mood, style, setting, etc.

(4) Advice and counsel in selecting artistic collaborative talent.

(5) Advice and counsel with regard to general practices in the entertainment industry as a whole.

(6) Advice and counsel concerning the selection and direction of agents, business Id.

managers, and other management personnel.

55. Thaler, supra note 35 , at 2 ; accord Cole-Wallen, supra note 4, at $486-87$ ("The personal manager advises, counsels, and directs the entertainer in the development, advancement, and enhancement of his artistic career."); Nimoy, supra note 35, at 147 ("[T] he primary function of a personal manager is to advise and counsel artists and to coordinate and supervise all business aspects of their careers.").

56. A business manager-usually an accountant or lawyer-may be hired to handle the artist's finances when the artist has developed sufficient cash flow to warrant such an expense. Cole-Wallen, supra note 4 , at 490 .

57. 1 TAUBMAN, supra note $33, \S 2.1$, at 34 .

58. Quast, supra note 2, at 198.

59. Id.

60. Id. ("The [personal manager] will . . . even manag[e] the artist's personal relationships, for the artists are often young, immature, [and] unsophisticated ....'). 
calls at all hours, ${ }^{61}$ and even pick up the chent's laundry. ${ }^{62}$

By orchestrating and momitoring the many aspects of the artist's personal and business life, the personal manager gives the artist time to be an artist. ${ }^{63}$ That is, managers liberate artists from burdensome yet essential business and logistical concerns so that artists have the requisite freedom to discharge their artistic function and to concentrate on their immediate creative task-writing a script, acting in a motion picture, recording a demo tape, or performing in a concert, for example. In this regard, the personal inanager is an indispensable element of an artist's career.

As compensation for their services, personal managers generally charge a commission of between $10 \%$ and $50 \%$ of the artist's gross receipts. ${ }^{64}$ Personal managers claim that their contributions to artists' careers justify this fee, which is typically higher than that charged by talent agents, because personal managers endure greater risk. Managers insist that because they take and build an unknown entertainer's career to full potential, they must have the ability on a long-terin contractual basis to charge a sufficient fee to cover the necessary costs of such developinent. ${ }^{65}$

No California law or entertainment-umion regulation expressly governs a personal manager's activities or fees. However, the California Entertainment Commission has interpreted the Talent Agencies Act as prohibiting a personal manager from seeking or procuring employment for a chent without a talent-agency license from the Labor Commissioner. ${ }^{66}$ This restriction persists as a major bone of contention between personal managers and the Labor Commissioner because, managers insist, it ignores entertainment-industry reality: any personal man-

61. See Wayne Wadhams, Sound Advice: The Musician's Guide to the Record INDUSTRY 76 (1990) (relating a manager's story about a phone call from the Georgia State Police after his artist-chent was picked up "for throwing firecrackers out the back of [a] van at 6:00 a.m. while doing $90 \mathrm{mph}$ on Route 95 South").

62. BasKerville, supra note 6 , at 154 .

63. Thaler, supra note 35 , at 2 .

64. STAFF ANALYSIS, supra note 43 , at 1 (personal management agreements may establish a fee as high as $40 \%$ to $50 \%$ of the artist's income); Quast, supra note 2, at 199 (personal managers may charge between $10 \%$ and $50 \%$, although fees of $10 \%$ to $25 \%$ are most common).

65. StafF ANALYSis, supra note 43, at 1 (higher fees justified because managers develop careers of new, unproven artists); Memorandum from California State Assemblyman Vic Fazio on Assembly Bill 2535 (as amended Apr. 24, 1978) Regarding Artists' Managers (Apr. 25, 1978) (summarizing hearing before Assembly Subcommittee on Labor, Employment, and Consumer Affairs on revisions to the Labor Code regarding artists' managers) (on file with author and California State Archives); Quast, supra note 2, at 199 (higher fees for personal managers warranted because of greater risk to managers than agents).

66. See ENTERTAINMENT COMMISSION REPORT, supra note 10, at 11-12 (no one may lawfully procure employment for an artist without first obtaining a license from the California Labor Commissioner); Cole-Wallen, supra note 4, at 488 (personal managers are prohibited from seeking or procuring employment for artists without a license). 
ager worth his or her commission partakes in some manner in procuring or attempting to procure einployinent for his or her clients. ${ }^{67}$ The restriction thus presents personal inanagers with an meluctable choice: they can either contmue their unlicensed procurement activities-and risk having their inanagement agreennents invalidated by the Labor Commissioner-or they can obtain talent-agency licenses-thus subjecting themselves to the Act's provisions and alerting the unions that because they have procured or intend to procure employinent for artists, union fee ceilings and other regulations should become operative against them. ${ }^{68}$

\section{Attorneys ("Entertainment Lawyers")}

Attorneys in the entertainment industry-so-called "entertainment lawyers"-perform essentially the same tasks as those discharged by any other legal practitioner. ${ }^{69}$ In fact, entertainment law is an ainalgamation of traditional legal concepts including contract, corporate, labor relations, taxation, real estate, tort, and copyright law. ${ }^{70}$ Attorneys in the industry may be employed to draft inanagement, agency, or other agreenients, to supervise or conduct negotiations, to organize the requisite docunientation for a foreign artist, or to estabhish a chient's loan-out company, for imstance. In essence, "[w] ered an entertainment attorney depends greatly upon the purpose for which the characterization is made, the nature of the inatters he handles and his overall chientele."71 Perhaps what most distingnishes entertainment lawyers froin other meinbers of the bar, and hence justifies the special inoniker, can be distilled into two critical benefits they bestow on their chents: a thorough knowledge of the internal workings of the entertainment industry and an abundance of contacts in the business.

While advising chents and exploiting contacts within the industry, attorneys, at a chent's request, occasionally enter the realm of the per-

67. Paul L. Brindze, California Assembly Bill 977: The Personal Manager's Relief Act, in 1983 HANDBOOK, supra note 10, at 247, 249 (discussing risks faced by personal manager seeking or procuring employment for an artist/client); see also Thaler, supra note 35, at 7-8 (stating that it is not uncommon for a personal manager to engage in procurement activities for his clients).

68. David F. Charles, Comment, The Personal Manager in California: Riding the Horns of the Licensing Dilemma, 1 HAsTINGs COMM. \& ENT. L.J. 347, 356 (1978). Licensure and regulation of personal managers is a controversy unto itself. See, e.g., id.

69. Leonard M. Marks, Ethical Aspects of Entertainment Law Practice, in CouNSELING Clients In the Entertainment Industry 1990, at 481, 483 (PLI Patents, Copyrights, Trademarks, and Literary Property Course Handbook Series No. 291) ("The entertainment lawycr performs all of the tasks associated with the legal profession-negotiating and drafting agreements, advising clients with respect to business matters and litigating to protect or defend their clients' rights in their compositions, performances, or persona.").

70. See Cole-Wallen, supra note 4 , at 490 .

71. Michael 1. Rudell, Behind the Scenes: Practical Entertainment Law 115 (1984). 
sonal manager or talent agent. ${ }^{72}$ The attorney usually acquiesces at first, emphasizing that this extralegal relationship will continue only until a suitable manager can be found. ${ }^{73}$ Despite this time qualification, attorneys later often hesitate to relinquish their roles as personal managers because they frequently derive more imcome from managing their artistchents than froin practicing law alone. ${ }^{74}$

This phenomenon of dual roles or secondary-related occupations (that is, attorney-manager or attorney-agent) often comphicates the already-intricate network of relationships that exists within the industry. It becoines difficult to ascertain in which capacity attorneys are acting and even more arduous to determine which set of rules governs their conduct. The entertainment lawyer can encounter three sources of regulation: legal-ethics rules, specialized legislation such as the Talent Agencies Act, and entertainment-union directives.

The first and inost obvious regulations the California attorney faces are the Professional Rules ${ }^{75}$ and the State Bar Act. ${ }^{76}$ These ethical rules govern the lawyer's conduct with respect to coinpetence, confidentiahty, fiduciary duties and conflicts of interest, advertisimg and solicitation, fees, and so forth. And although there is no express rule forbidding California attorneys froin engaging in related secondary occupations-such as attorney-agent or attorney-inanager-they are bound by the state's legalethics rules if they do so. ${ }^{77}$ Second, attorneys who provide procurement services for their artist-chents are likely to be subject to the proscriptions of the Act because the Labor Commissioner has established that only a licensed talent agent may procure einployment for an artist. ${ }^{78} \mathrm{Third}$

72. See TAubman, supra note 42 , at 88 (in the process of giving advice to clients, attorneys sometimes drift into manageinent); 1 TAUBMAN, supra note $33, \S 2.8$, at 47 ("Because tlie managerial functiou is inextricably bound witl problems of law and contracts, sometimes counsel gravitate into the managerial function and, iu fact, become managers side by side witl law practice."); Cole-Wallen, supra note 4, at 483 ("Faced witl an increased demand for services outside the traditional legal role and various market pressures, it is not surprising that many attorneys liave entered into secondary occupations within the entertainment industry.").

73. BASKERVILLE, supra note 6 , at 162 .

74. See id.

75. Professional Rules, supra note 29.

76. CAL. Bus. \& Prof. Code $\$ \S 6000-6228$ (West 1990 \& Supp. 1991). Althougl California's Professional Rules are not modeled after the American Bar Association Model Rules of Professional Conduct or Model Code of Professional Responsibility, a California attorney may nonetlieless consider the standards and opinions generated by jurisdictions tliat follow those rules. See Professional Rules, supra note 29, Rule 1-100(A) ("Etlics opinions and rules and standards promulgated by other jurisdictions and bar associations may also be considered.").

77. See ABA Comm. on Etlics and Professional Responsibility, Formal Op. 328 (1972) [hereinafter Formal Op. 328] ("A lawyer who is engaged . . . in the practice of law and in another profession or occupation whicl is closely related to law must conform to the Code of Professional Responsibility in conducting suclı activities."); RAYMOND L. WisE, LEGAL ETHICs 185 (2d ed. 1970) ("It is not improper for a lawyer to engage in a separate business or profession provided in doing so he does not violate the canons of legal ethics.").

78. See supra note 10. 
once it is determined that the attorney has performed the tasks of a talent agent, the regulations of the entertainment unions and guilds niay be called nito effect as well. For example, Screen Actors Guild regulations provide that attorneys-at-law are not agents unless their services to artistnienibers include solicitation of einployinent in inotion pictures for nen1bers or the lawyers engage generally in the activities of an agent. ${ }^{79}$

The entertainment lawyer's fees can be determined using six alternative niethods: (1) hourly billing; (2) nonthly or annual retainers; (3) flat fees for particular services; (4) a percentage of the artist's contract; (5) a percentage of the artist's inconie; or (6) where lawyer and artist enter a partnership, a percentage of all noney arisnig froin the partnership. ${ }^{80}$ If fees are not set out in advance, lawyers are entitled to compensation in an amount equal to the reasonable value of their services. Attorneys' fees are limited by a standard of reasonableness and can be reduced if found unconscionable. $^{81}$

While the entertainment attorney's practice is not radically different froin that of other attorneys, the requirenients for success and the coinciding rewards can be notably unique. First, "[t]he intangible attribute on which the success of an entertainment attorney invariably rests ... [is] an ability to understand and deal with the 'artistic tenıperament' so often possessed by his chents" inents within an impassioned, creative, and often highly spontaneous setting. ${ }^{83}$ Second, in addition to potentially high conipensation, the entertainment attorney's rewards "include the handling of fascinating subjects which often coine to hfe in productions or performances and the fulfillment of contributing to endeavors which bring pleasure to nasses

79. See Neville L. Johnson \& Daniel W. Lang, The Personal Manager in the California Entertainment Industry, 52 S. CAL. L. REV. 375, 414 n.195 (1979) (citing Constitution and By-Laws of Screen Actors Guild, Inc. (SAG) § I-G, at 1). The SAG defines an agcnt as a

person, copartnership, association, firm or corporation who or which offers to or does represent, act as the representative of, negotiate for, procure employment for, counsel or advise any member of the SAG in and about and in connection with or relating to his employinent or professional career as an actor in the production of motion pictures.

Id. at 413 n.195 (quoting Rules and Regulations of SAG, Rule 16(g), § I-C, at 1).

The American Federation of Musicians of the United States (AF of M) By-Laws define an agent as " 'any person ... who for a fee procures, offers, promises, or attempts to procure employment or engagements for musicians whether or not, in addition to such activities, he or it performs additional services for musicians as artists' manager or personal manager or otherwise.' "Id. (quoting Constitution By-Laws and Policy of the American Federation of Musicians of the United States and Canada art. 25, $\$ 2$, at 144).

It is relatively clear that an attorney who engages in the described conduct falls within the SAG and AF of M definitions of "agent." Consequently, the lawyer would be subject to the same franchising, compensation, and other union regulations as the talent agent.

80. Cole-Wallen, supra note 4 , at 522.

81. Professional RUles, supra note 29, Rule 4-200(A) ("A member shall not enter into an agreement for, charge, or collect an illegal or unconscionable fee.").

82. RUDELL, supra note 71 , at 117.

83. See Cole-Wallen, supra note 4 , at 490 . 
of people."84

\section{Guilds and Unions ${ }^{85}$}

The powerful entertainment guilds and unions promulgate and enforce complex rules to protect their artist-members from sharp and overreaching practices by personal representatives. They have also been influential in the legislative arena, pressuring the California Legislature to pass and amend the various permutations of the Act. Five major talent umons actively momitor relationships between members and their representatives: the American Federation of Musicians (AF of M), the American Federation of Television and Radio Artists (AFTRA), the Screen Actors Guild (SAG), the Directors Guild of America (DGA), and the Writers Guild of America (WGA).

With respect to regulation of an artist's personal representatives, union and guild restrictions are generally considered to be more comprehensive, far-reaching, and rigorous than state-generated controls. ${ }^{86}$ The unions' vigorous protection of their artist-members focuses on the relationship between artist and talent agent (or those who procure employment for artist-members) ${ }^{87}$ For example, unions regulate individuals who act as talent agents by limitimg fees, requiring the use of form contracts or pro-artist provisions, restricting the term of agreements, and demanding that the agent execute a franchise agreement with the union. Talent agents are not the ouly individuals affected by union and guild restrictions, however-personal managers and attorneys also may be regulated to the extent that they engage in procurement activity. ${ }^{88}$

II

\section{Operation and Regulations of the Talent Agencies Act}

The Act's regulatory regime is detailed and comprehensive. Sections 1700 to 1700.4 are the definitional provisions. Section 1700.5 compels all individuals or organizations who engage in procurement activities to obtam a hicense from the Labor Commissioner. Sections

84. RUDELl, supra note 71 , at 118.

85. Entertainment guilds and unions can be broadly categorized into "above-the-line" unions, representing "artistic talent such as directors, writers, and performers," and "below-the-line" unions, representing "technical and craft employees such as grips, electricians, and film editors." The Motion Picture \& Television Business: Contracts and Practices $\$ 4.01$ (rev. no. 1 1987). "Above-the-line" unions are the focus of this discussion.

86. Cole-Wallen, supra note 4, at 512.

87. Id. at 519 .

88. Id. at 520 ("Regardless of whether one is an attomey, personal nanager or business manager, if he solicits business for an artist, the unions would seek to regulate the activity."); see also Johnson \& Lang, supra note 79, at 413 n.195 (discussing AF of M By-Laws and SAG Rules and Regulations with respeet to regulation of business managers, personal managers, and attorneys); supra note 79 and accompanying text. 
1700.6 through 1700.22 set forth particular licensing procedures, froin tlie completion of an application to a surety bond requirement. Sections 1700.23 to 1700.41 govern the business affairs of talent agents, inandating Labor Commission approval of form agreements between agents and artists and prohibiting certain types of conduct. Section 1700.44(a) gives the Labor Commissioner original jurisdiction over disputes arising under the Act; he or she may liear all such controversies subject to a one-year statute of limitations and the riglit to appeal de novo to the superior court. A more detailed analysis of the Act's primcipal provisions follows.

\section{A. Labor Commissioner's Original Jurisdiction}

Section 1700.44(a) provides: "In cases of controversy arising under this chapter, the parties mvolved shall refer the matters in dispute to the Labor Commissioner, who shall hear and determine the saine."89 This section confers original and exclusive jurisdiction upon the Labor Commissioner to hear and determine all disputes regarding potential violations of the Act. ${ }^{90}$ Section 1700.44(a) is compulsory in disputes between artists and individuals allegedly performing talent-agency services, even when the charged party is unlicensed. ${ }^{91}$ Therefore, an individual cannot circumvent the Labor Coinmissioner's jurisdiction simply by failing to obtain a license or by utilizing some other contrived stratagem or subterfuge. ${ }^{92}$

\section{B. Applications, Fees, and Bonds}

The Act requires prospective licensees to submit an application that includes their name, address, and prior occupation as well as the names, addresses, and prior occupations of their partners and associates. Applicants must attacli their fingerprimts, at least two affidavits from respectable members of the coinununity vouching for their "good moral character," $" 93$ and a filing fee; they must pay an annual license fee if the hicense is issued. ${ }^{94}$ Section 1700.15 , which compels the applicant to

89. Cal. Lab. CoDE $\S 1700.44$ (a) (West 1989).

90. See Buchwald v. Superior Court, 62 Cal. Rptr. 364, 372 (Ct. App. 1967) (holding that in cases arising under the Act, the Labor Commissioner has original jurisdiction to the exclusion of the superior court); Singer, supra note 10, at 255 (stating that Labor Commission has original jurisdiction over unlicensed individuals performing talent agency services).

91. Singer, supra note 10, at 255 ("[T] he jurisdiction of the Labor Commissioner is . . . over those individuals who perform services of a talent agent whether they are licensed or unlicensed.").

92. See id. at 256-57 (discussing Pryor v. Franklin, No. TAC 17 MP 114 (Cal. Labor Comm'r 1982), which found the Labor Commissioner had jurisdiction despite defendant's claim that he was acting as attorney, personal manager, and loan-out corporation officer rather than as talent agcnt).

93. Cal. LAB. CODE $\S 1700.6$ (West 1989).

94. The "filing fee" is minimal (currently $\$ 25$ ), but the annual license fee is a more significant sum (currently \$225). Id. $\S 1700.12$. 
deposit a $\$ 10,000$ surety bond with the Labor Commissioner, ${ }^{95}$ is perhaps the most disdained requirement of the Act. The bond is intended to ensure coinpliance with the Act and to guarantee some reimbursement to aggrieved artists when the Commissioner finds that a licensed talent agent has violated the Act's provisions.

\section{Business Practices and Prohibitions}

The Labor Commissioner is empowered to require talent agents to subinit their form contracts for approval, but such approval cannot be withheld unless the proposed contract is "unfair, unjust and oppressive to the artist."96 Talent agents are required to file a fee schedule describing the charges to be levied in the operation of the agency, ${ }^{97}$ and new fees cannot becoine effective until seven days after they are filed with the Labor Commissioner and posted in a "conspicuous" place in the talent agent's office. ${ }^{98}$

Talent agents inust deposit any funds collected on behalf of the artist in a trust-fund account, disburse such momies to the artist (less coinmission) within fifteen days after receipt, and inaintain separate records of such funds. ${ }^{99}$ The talent agent inust keep additional records of each artist's name and address, each artist's engageinents and coinpensation, and the ainount of fees collected. ${ }^{100}$ These records inust be available to the Labor Commissioner upon reasonable dernand. ${ }^{101}$

The Act also prohibits licensed agents from engaging in certain types of conduct. They cannot publish false, fraudulent, or misleading information or advertisements, ${ }^{102}$ dispatch artists to unsafe locations, ${ }^{103}$ split fees with an employer, ${ }^{104}$ or charge a "registration fee." ${ }^{105}$ Nor inay a talent agent send a minor to any place where liquor is sold and consuined, ${ }^{106}$ permit persons of bad character to frequent or be employed at

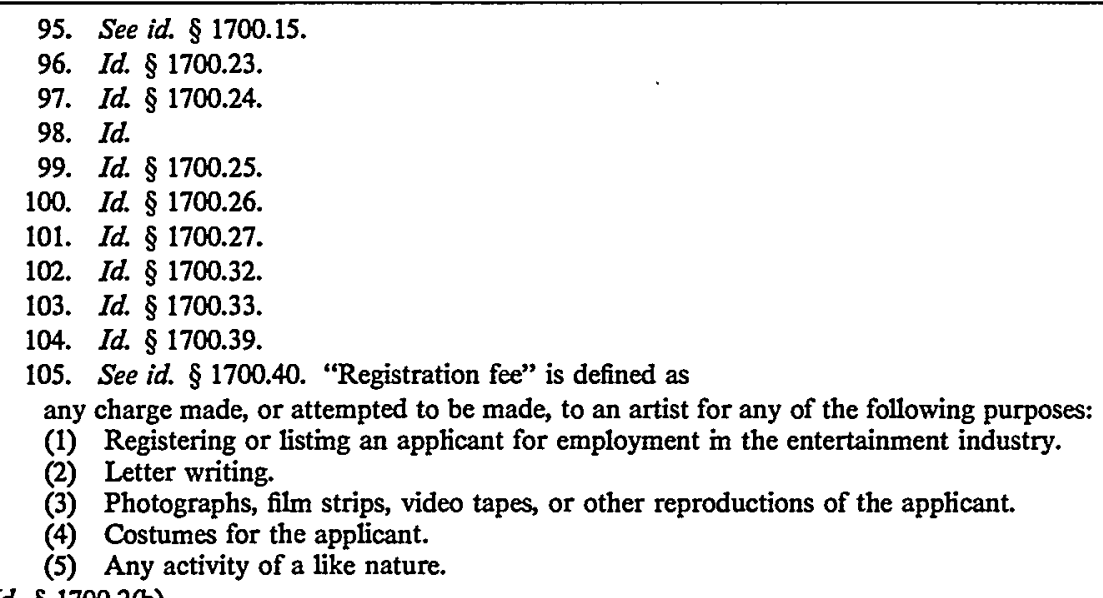

Id. $\S 1700.2(\mathrm{~b})$.

106. Id. $\S 1700.34$. 
the agency, ${ }^{107}$ secure employment for an artist in any location where labor trouble exists without first imforming the artist of the condition, ${ }^{108}$ or issue a contract for employment contaiming provisions that, if comphed with, would be in violation of the law. ${ }^{109}$

\section{Proceedings Before the Labor Commissioner}

An adınimistrative proceeding is initiated by filing a "Petition to Determine Controversy" with the Labor Commissioner's office. ${ }^{110}$ A copy of the petition must be served on the opposing party who then has twenty days to serve and file an answer. ${ }^{111}$ If the Labor Commissioner can establish by investigation that no dispute regarding the amount of fees due exists, however, he or she may certify without a hearing that there is no real controversy. ${ }^{112}$

As a rule, "hearing officers," who are usually attorneys within the Division of Labor Standards Enforceinent actmg pursuant to the authority of the Labor Commissioner, preside over the administrative proceedings. ${ }^{113}$. If a hearing is conducted and the dispute is not settled, dismissed, or otherwise disposed of, the hearing officer will issue a "Determination and Award," similar to a judicial opimion, describing the factual situation, applicable rules, reasoning, and award, if any. ${ }^{114}$

Once a decision is rendered, the aggrieved party is granted two separate rights: the right to appeal ${ }^{115}$ and the right to stay execution of an award pending appeal by executing a bond approved by the superior court. ${ }^{16}$ If the appealing party fails to execute the bond, the prevaiting party can move to confirm the Labor Cominissioner's award and upon confirmation enforce the resulting judgment. ${ }^{117}$ The aggrieved party's right to appeal, however, remains unaffected because section 1700.44(a) contains no language conditioning the right to appeal upon the filing of a bond. ${ }^{118}$ The Supreme Court of Califorina has held that section 1700.44(a) entitles the appealing party to a new hearing in the superior court - that is, more than sinply a review of the former proceedings ${ }^{119}$

107. Id. § 1700.35 .

108. Id. $\S 1700.38$.

109. Id. § 1700.31 .

110. CAL. Code Regs. tit. 8, § 12022 (1990).

111. Id. §§ 12024-12025 (1990).

112. CAL. LAB. CODE $\$ 1700.44$ (a) (West 1989).

113. Interview with Fred Duscha, Attorney, State of California Department of Industrial Relations, Division of Labor Standards Enforcement, in San Francisco, Cal. (Mar. 8, 1991).

114. Id.

115. CAL. LAB. CODE $\S 1700.44$ (a) (West 1989). Appeal to the superior court must be made within ten days of the Labor Commissioner's determination. Id.

116. Id.

117. Buchwald v. Katz, 503 P.2d 1376, 1378-79 (Cal. 1972).

118. Id. at 1378.

119. Id. at 1381. 
although the superior court may call up any documents used by the parties to present their claims and defenses in the Labor Commissioner hearing. ${ }^{120}$ Fimally, section 1700.44(c) imposes a one-year statute of limitations. ${ }^{121}$ Prior to the addition of this limitation period, artists were permitted to recover past fees and commissions paid over the life of the contractual relationship. This restriction, however, bars old disputes and also effectively hmits recovery to fees and commissions earned during the one-year period preceding the filing of the action, ${ }^{122}$ although even that amount can be substantial.

\section{E. Remedies and Enforcement}

The Labor Commissioner has extensive authority to fashion a remedy for violation of the Act. First, "[i]f the Labor Commissioner determines that an individual acted as a talent agent without having obtained a license ... then any agreement entered into between the artist and the unlicensed talent agent pertaining to unlawful procurement activities will be declared void."123 Upon a determination that the artist-agent contract is invalid, the Labor Commissioner may proclaim that the agent is entitled to no further fees or commissions, ${ }^{124}$ that the artist is not liable for any money advanced to him by the agent to promote the artist's career, ${ }^{125}$ that the artist can collect restitution of all funds paid to the unlicensed individual, ${ }^{126}$ and/or that the agent is entitled to keep certaim or all compensation on the basis of quantum meruit. ${ }^{127}$ Negation of the agreement between the artist and the unlicensed individual also renders any collateral agreements or contracts executed by the parties invahd. ${ }^{128}$ Such rehef thus does more than divest talent agents of past compensation-it can also force them to forfeit prospective interests they may have in the artist's product, such as future royalties.

120. Id. at 1382 .

121. CAL. LAB. CODE $\S 1700.44$ (c) (West 1989) ("No action or proceeding shall be brought pursuant to this chapter with respect to any violation which is alleged to have occurred more than one year prior to commencement of the action or proceeding.").

122. Fred Jelin, The Personal Manager Controversy, L.A. LAw., Jan. 1985, at 23, 24; see also Brindze, supra note 67, at 253 ("[T]he one-year statute of limitations eliminates the ultimate horror of representing an act for a number of years and then being required to repay all comınissions earned for all those years.").

123. ENTERTAINMENT Commission Report, supra note 10, at 17-18 (Labor Coinmissioner has power to declare any contract between unlicensed talent agent and artist void); Singer, supra note 10 , at 258 .

124. Singer, supra note 10 , at 258 .

125. Gary A. Greenberg, Comment, The Plight of the Personal Manager in California: A Legislative Solution, 6 HASTINGs CoMM. \& ENT. L.J. 837, 853 (1984).

126. Singer, supra note 10 , at 258.

127. Id.

128. Greenberg, supra note 125 , at 853 (citing Derek v. Callan, No. TAC 18-80 (Cal. Labor Comm'r 1982)). 
The Labor Commissioner's authority to fashion remedies and penalties provides the artist with significant protection from an individual who has unlawfully acted as a talent agent. As a result, the Act has been wielded by artists as a sword to reclaim fees from personal representatives. The Act is not self-enforcing, however. It must be activated by complaints, either from artists alleging unlicensed procurement or from agents atteinpting to recover delinquent fees. ${ }^{129}$ This inechanism has motivated some commentators to insist that the Act is, for all practical purposes, ineffective. ${ }^{130}$ Despite this asserted insufficiency, the Act has become a powerful statute, and the full force of a Labor Commissioner determination and award can inflict serious financial and professional misfortune on the unwary unticensed individual. ${ }^{131}$

\section{III}

\section{JUSTIFICATIONS FOR EXPRESS EXEMPTION OF ATTORNEYS FROM THE TALENT AGENCIES ACT}

Reinoving attorneys from the Labor Commissioner's jurisdiction under the Act is essential if the Act is to be a model statute in this country. ${ }^{132}$ Exempting lawyers from the proscriptions of the Act is justified on several grounds. First, attorneys should be exeinpted because the Act was never intended to apply to their activities. Prevailing interpretations of the Act, to the extent that they regulate the conduct of attorneys engaged in procurement activity, have forsaken original legislative intent.

Second, ambignous langnage renders the Act inherently unjust because it does not give fair and adequate warning of the type of activity that constitutes procurement and it does not provide a consistent standard that the Labor Commissioner can apply to determine whether an individual has violated the Act. Moreover, the Labor Commissioner has held that certain conduct-such as contract negotiations-constitutes procurement; such decisions transform customarily permissible legal activity into illicit conduct when engaged in by attorneys who are not hicensed as talent agents. These decisions, if apphed to attorneys, seein even more unreasonable when one realizes that contract negotiations constitute the "largest portion of work that an attorney will perform for an artist." 133

Third, lawyers should be exempt from the Act's regulations because

129. See Cole-Wallen, supra note 4, at 516 ("In the absence of a complaint, the Labor Commission rarely initiates overt action to enforce the Act's provisions.").

130. See id. (noting observations by commentators that the Act "has no substantive impact"),

131. See supra text accompanying notes 13-27.

132. The California Entertainment Commission was directed by statute to recommend changes to the Act that would make it a model statute in the United States. ENTERTAINMENT CoMmission REPORT, supra note 10, at 3-4.

133. Cole-Wallen, supra note 4 , at 491. 
the Professional Rules and the State Bar Act govern nearly every conceivable activity or impropriety of an attorney practicing within the state. These rules, designed specifically to regulate the conduct of lawyers, provide greater protection to artists than the Act does. Furthermore, many of the Act's regulations are repetitive in hight of California's legal-ethics rules and in some instances conflict with those rules. In sum, the Professional Rules and the State Bar Act are sufficient to safeguard artists from any unscrupulous conduct by lawyers, and the California Legislature has failed to express any convincing pohicy justification for attorney hicensure under the Act. ${ }^{134}$

\section{A. Purpose and Legislative History of the Talent Agencies Act as a Basis for Attorney Exemption}

The avowed purpose of the Talent Agencies Act is straightforward: to protect artists who are seeking employment or attempting to advance their careers in the California entertainment mdustry. ${ }^{135}$ Certain improprieties by talent agents were brought to the attention of the California Legislature, thus providing the impetus for the remedial legislation that would eventually become the Talent Agencies Act. There was concern that unlicensed individuals were acting improperly by, for example, sending aspiring female artists to houses of prostitution under the pretense that the job was in furtherance of their artistic careers. ${ }^{136}$ The legislation preceding the Act was directed specifically at regulating such untoward activity. ${ }^{137}$ At no time during the legislative process, however, were attorneys implicated in such wrongdoimg.

California's Talent Agencies Act evolved out of the state's Private Employment Agencies Law of 1913. ${ }^{138}$ In 1943 legislation intended to

134. Talent agents often argue that there is no justification for exempting anyone who "procures" employment from the Act's directives on the ground that to grant such exclusions is unfair because such an exemption would allow unlicensed individuals to compete with agents for clients without bearing any of the burdens inposed by the Act. See ENTERTAINMENT CoMmission REPORT, supra note 10, at 8-9. While this argument is not without force, it may be challenged in several ways. First, agents have never complained about competition from attorneys, suggestimg that such competition is not a problem for agents. Second, one of the realities of practicing law in the entertainment industry is that lawyers imvolved in their clients' careers must necessarily engage in certain activities which may be construed as procuring employment, such as negotiating employment contracts. See infra text accompanying notes 172-77. Finally, the arguments proposed in the text also serve to rebut the agents' contentions.

135. See Hearings, supra note 10, at 189 (testimony of Albert Reyff, Asst. State Labor Comm'r).

136. Id. at 28-29 (testimony of Roger Davis, First Vice Pres. of the Artists' Managers Guild).

137. Id.

[T]here was a real need for regulation of employment agencies and particular ... [talent agents], and that's why the legislature did it. It was no accident. It was done at the request of people who were concerned about the fact that ... [talent agents] or people operating in Id. that arca were acting improperly ....

138. Philip R. Green \& Beverly R. Green, Talent Agents and the New California Act, in 1988 
regulate talent agents was incorporated into the regulatory regime applicable to employment agencies in general in order to bring agents under the jurisdiction of the Labor Commissioner. ${ }^{139}$ In 1959, however, talent agents received their own chapter of the Labor Code-the Artists' Managers Act-reflecting the legislature's increased realization that "the business of procuring einployinent in the entertainment industry . . . is different and in inany ways inore coinplex than the business of the normal einployinent agencies the Labor Coinmissioner regulates." 140 The changes were inade at the insistence of talent agents who coinplained that they were subject to rules not specifically proinulgated to regulate them. ${ }^{141}$

In 1967 the Labor Code sections concerning einployment agencies were repealed and jurisdiction was removed to the Bureau of Employment Agencies, ${ }^{142}$ and in 1978 the Artists' Managers Act becaine the Talent Agencies Act. The Talent Agencies Act clarified that talent agents were under the province of the Labor Commissioner and not the Bureau of Employinent Agencies. ${ }^{143}$

In 1982, in order to dispel confusion surrounding the Act and its apphcability, rehief was again sought in the legislature. Three notable amendments were added to the Act, subject to "sunset" provisions that would terminate the ainendinents unless reinstated by the legislature. The amendments (1) allowed an unlicensed individual to act in conjunction with and at the request of a licensed talent agent in the negotiation of an employinent contract; ${ }^{144}$ (2) reinoved the sohitation and procurement of a recording contract from regulation; ${ }^{145}$ and (3) introduced a one-year statute of limitations. ${ }^{146}$ These ainendinents were set to selfdestruct on January 1, 1986. ${ }^{147}$

The 1982 amendments also created the California Entertainment

Entertalnment, Publishing and the ARTs Handbook 357 (John D. Viera \& Robert Thorne eds.). The Act is a perfect example of interest-group politics supplanting legislative integrity. The Act progressed from conception to present form in slow stages directed primarily by the forces of interested parties, bargained additions and modifications, and heated industry debate. Interested groups such as the Association of Talent Agents changed sides frequently, opposing in one instance the powerful entertainment umions and in the next joining them against personal managers or other potential procurers.

139. Id. (Act of May 2, 1943, ch. 329, 1943 Cal. Stat. 1326).

140. Id.

141. Letter from John F. Henning, Director of the California Department of Industrial Relations, to Julian Beck, Legislative Secretary, Governor's Office (May 28, 1959) (on file with author and California State Archives).

142. Act of Aug. 28, 1967, ch. 1505, secs. 2-3, 13-14, 1967 Cal. Stat. 3571, 3572.

143. Talent Agencies Act, ch. 1382, sec. 6, 1978 Cal. Stat. 4575, 4576.

144. Act of Aug. 31, 1982, ch. 682, sec. 3, 1982 Cal. Stat. 2814, 2815-16 (codified at amended at CAL. LAB. CoDE $\S 1700.44$ (d) (West 1989)).

145. Id. at 2814 (codified as amended at CAL. LAB. CODE $\S 1700.4$ (a) (West 1989)).

146. Id. at 2815 (codified as anended at CAL. LAB. CODE $\$ 1700.44$ (c) (West 1989)).

147. Act of July 17, 1984, ch. 553, sec. 7, 1984 Cal. Stat. 2185, 2187. 
Commission to study the entertainment industry and to recommend a model bill to the legislature. ${ }^{148}$ The Entertamment Commission, after two years of deliberation on six issues, voted to remove the sunset provisions and inaintain all the 1982 amendments. ${ }^{149}$ The legislature adopted the Entertainment Commission's recominendations, with minor language changes, and they were signed into law in $1986 .{ }^{150}$ No inajor changes have occurred since.

In its 1985 report the Entertainment Commission inaintained that the Act applied to any person who engaged in procureinent activity. ${ }^{151}$ The Entertainment Commission, in its struggle to identify tllose activities in which unlicensed individuals, including attorneys, could engage when procuring employinent for an artist, concluded

that there is no such activity, that there are no such permissible limits, and that the prohibitions of the Act over the activities of anyone procuring einployment for an artist without being hicensed as a talent agent must reinain, as they are intended to be, total. ... [O]ne either is, or is not, licensed as a talent agent, and, if not so licensed, one cannot expect to engage, with impuinty, in any activity relating to the services which a talent agent is licensed to render. ${ }^{152}$

According to the Entertainment Commission, therefore, anyone who solicits or procures employment for an entertainer comes under the Labor Commissioner's authority to resolve claims made against that person, even if such a person chooses to classify his or her activities as those of an attorney, personal manager, business inanager, officer of a loan-out

148. Act act. of Aug. 31, 1982, ch. 682, 1982 Cal. Stat. 2814, 2816, repealed by Act of July 17, 1984, ch. 553, 1984 Cal. Stat. 2185 (effeetive Jan. 1, 1986). The Commission was composed of three artists (Ed Asner, John Forsythe, Cicely Tyson), three talent agents (Jeffrey Berg, Roger Davis, Richard Rosenberg), three personal managers (Bob Finklestem, Patricia McQueeney, Larry Thompson) and the State Labor Commissioner (C. Robert Simpson, Jr.). ENTERTAINMENT COMMISSION REPORT, supra note 10, at 2.

149. The Commission considered the following issues:

(1) Under what conditions or circumstances, if any, should a personal manager or anyone other than a licensed talent agent be allowed to procure, offer, promise or attempt to procure employment or engagements for an artist without being licensed as a talent agent? ... [None.]

(2) What changes, if any, should be made in the provisions of the Act exempting from the Act a person who procures recording contracts for an artist? [None.]

(3) Should the criminal sanctions of the Act, removed by AB 997, be reinstated and, if so, in what form? [No.]

(4) Should the sunset provisions added to the Act by AB 997 be deleted? [Yes.]

(5) Should the entire Act be repealed and/or should there be a separate licensing law for personal managers? [No.]

(6) What other changes, if any, should be made in the Act? [The Commission recommended several administrative, technical, and housekeeping changes.]

ENTERTAINMENT COMMISSION RePORT, supra note 10, at 5.

150. Act of July 24, 1986, ch. $488,1986 \mathrm{Cal}$. Stat. 1804 (effective Jan. 1, 1986).

151. ENTERTAINMENT COMMISSION REPORT, supra note 10, at 20.

152. Id. at 11 (emphasis added). 
company, or joint venturer. ${ }^{153}$ Labor Commissioner determinations espouse similar views. ${ }^{154}$

The interpretations of the Act by the Entertainment Commission and the Labor Commissioner, as definitive as they seem, are in clear contradiction to statements by legislators and others mvolved in the lawmaking process. For example, California State Senator Whetmore emphatically asserted that the Act was not drafted with an intent to include the activities of lawyers. ${ }^{155}$ An exchange between the then-vicepresident of the William Morris Agency, Roger Davis, and Califorma State Senator Robert Presley during the legislative process also indicated that lawyers were not required to be hicensed under the Act (ostensibly because the California Bar had the strength to resist such regulation of its inembers), ${ }^{156}$ and suggested further that regulating the conduct of attorneys under the Act was unnecessary duphication. ${ }^{157}$ Finally, an individual involved in draftimg the 1959 Artists' Managers Act expressed his behef that attorney conduct was not intended to be covered by the Act because lawyers already had a hicense; rather, it was unlicensed individuals who were the target of the Act's provisions. ${ }^{158}$ What is even 1nore striking about the entire legislative process, however, is the noticeable absence of any substantial discussion concerning the regulation of attorney behavior. This, at the very least, supports by negative implication that attorney conduct was not a target of the Act's regulations.

In sum, this analysis of the Act's history and its acknowledged purpose support the contention that the Act was neither designed nor intended to affect the activities of lawyers. To the extent that the entities charged with the Act's enforcement and imterpretation maintain that an attorney's conduct is proscribed, they have unjustifiably expanded the scope of the Act by disregarding the Act's legislative history and the intent of the drafters.

\section{B. Ambiguous Language of the Talent Agencies Act as a Basis for Attorney Exemption}

\section{Absence of a Definition of Procurement}

The Talent Agencies Act defines a talent agent as a person or corporation who procures, offers, promises, or attempts to procure employ-

153. This does not affect the Act's exceptions for an individual who procures, offers, or promises to procure a recording contract, CAL. LAB. CoDE $\$ 1700.4$ (a) (West 1989), or a person who works with and at the request of a licensed talent agent, id. $\S 1700.44(d)$.

154. See infra Section III.B.1.

155. See Hearings, supra note 10, at 20.

156. See id. at 43 (testimony of Roger Davis).

157. See id. at 45 .

158. See id. at 113, 120-21 (statement of Walter L.M. Loriner). 
ment for an artist. ${ }^{159}$ Accordingly, whether or not one is a talent agent subject to the Act's restrictions is determined by participation in procureinent activity, for "[i]t is not a person who is being hicensed by the Talent Agencies Act: rather, it is the activity of procuring employment. Whoever performs that activity is legally defined as a talent agent." 160 In order to find a violation of the Act, therefore, it must be establislied that one party is an "artist" and that the otlier party engaged in procureinent activity without first obtaining a license.

A significant ambiguity was drafted into the Act, lowever, when the Califorma Legislature neglected to define procurement. The term procurement is so unclear and ambiguous that it leaves reasonable people guessing as to its ineaning or wliether a violation lias occurred; consequently, unlicensed representatives (including attorneys) are unfairly exposed to often staggering potential liability. ${ }^{161}$ More importantly, the liberal construction of procurement advocated by the Labor Commission renders a number of tasks traditionally performed by attorneys unlawful witliout a talent-agency hicense. ${ }^{162}$ The legislature's failure to define the term procurement, and the judiciary's and Labor Commission's mability to formulate a coherent definition, unfairly subjects attorneys to tlie Act's potentially severe remedies when they perform traditionally legal functions.

Because tlie California Labor Commissioner, rather tlian the judiciary, has origunal jurisdiction over disputes between artists and alleged talent agents, ${ }^{163}$ most decisions that would aid in decipliering the term procurement are unreported. Therefore, it is necessary to look primarily to Labor Commissioner determinations ${ }^{164}$ and the Report of the Califorma Entertainment Commission ${ }^{165}$ as sources for determining the meaning of procureinent. Unfortunately, while some specific activities

159. See CAL. LAB. CoDe $\S 1700.4$ (a) (West 1989).

160. ENTERTAINMENT CoMmission REPORT, supra note 10, at 20 (emphasis added).

161. See supra text accompanying notes 13-21.

162. See infra text accompanying notes 167-77.

163. See supra text accompanying notes 89-92.

164. The following information is based on my personal observations: Utilizing hearing officers who are often attorneys in the Division of Labor Standards Enforcement, the Labor Commissioner hears Talent Agencies Act controversies im offices throughout the state. All determinations and case files, however, are returned to the central office in San Francisco, where they are available upon request. Unfortunately, these rccords are disorganized and unindexed; there is also a considerable lag time-more than a year-between institution of a controversy and its resolution. Between 1985 and the early months of 1990, there appear to have been 165 Act controversies initiated before the Labor Commissioner. This number represents more than a $500 \%$ increase over a roughly five-andone-half year period from December 1977 to September 1983. See Karen A. Julian, Personal Manager or Talent Agent? A Summary of Recent California Labor Commission Findings in Regulation of Entertainers' Representatives, in 1983 HANDBOOK, supra note 10, at 315, 315 (stating that 31 cases were filed before the Labor Commissioner between December 1977 and September 1983).

165. ENTERTAINMENT COMmission RePORT, supra note 10, at 6-12. 
have been identified as constituting procurement, ${ }^{166}$ the deciding tribunal rarely provides a satisfying-that is, consistent-rationale and, consequently, no well-defined parameters have been articulated.

The California Labor Commissioner and the few courts scrutinizing Talent Agencies Act controversies have broadly interpreted the notion of procurement and have effectively ignored legislative intent, ${ }^{167}$ essentially determining that any attempt to solicit employment on belialf of an artist can be construed as procurement activity. For exainple, the courts and the Labor Commissioner have concluded, in various factual situations, that the following activities by unlicensed representatives constitute unlawful procurement: introducing artists to producers or directors; ${ }^{168}$ initiating contacts witl employers; ${ }^{169}$ furthering an offer for an artistclient; ${ }^{170}$ and negotiating einployinent contracts. ${ }^{171}$

For attorneys, the inost foreboding decisions issued by the Labor Commissioner and the courts are those equatimg contract negotiationsa function attorneys traditionally perforn-with illegal procurement activity. In Kearney v. Singer, ${ }^{172}$ for example, the Labor Commissioner held that negotiatimg an offer constituted unlicensed procurement activity. ${ }^{173}$ This was confirmed in St. Louis $v$. Wolf ${ }^{174}$ in which the hearing officer declared that " 'procurement' includes a negotiation whose directed or logically intended purpose is to inarket an artist's talent." 175 In Pryor v. Franklin, ${ }^{176}$ the Labor Commissioner defined procurement "to include the legal function of contract negotiations."177 Altlough all

166. For a list of some activities the Labor Commissioner has recognized as constituting "procurement," see infra notes 168-71 and accompanying text.

167. See supra text accompanying notes $135-58$.

168. See Greenberg, supra note 125, at 853 (suggesting in discussion of Derek v. Callan, No. TAC 18-80 (Cal. Labor Comm'r 1982), that introducing an actress to a motion picture producer constitutes procurement).

169. See Singer, supra note 10, at 257-58 (suggesting in discussion of Pryor v. Franklin, No. TAC 17 MP 114 (Cal. Labor Comm'r 1982) that initiating contacts intended to market artist's talent constituted procurement).

170. See Julian, supra note 164, at 319-21 (discussing Kearney v. Singer, No. MP 429, AM 211 MC (Cal. Labor Comm'r 1978)).

171. See Julian, supra note 164, at 319-24 (discussing Kearney and St. Louis v. Wolf, No. TAC 29-79 (Cal. Labor Comm'r 1981)); Singer, supra note 10, at 256-61 (discussing Pryor and suggesting that procurement includes the legal function of negotiations); see also Singer, supra note 10, at 258 (stating that under current decisions of the Labor Commissioner, "merely the negotiation of an employment agreement ... for an artist will constitute 'procurement' and the type of activity that will be subject to review by the Labor Commissioner").

172. No. MP 429, AM 211 MC (Cal. Labor Comm'r 1978), discussed in Julian, supra note 164, at 319-21.

173. Julian, supra note 164 , at 321.

174. No. TAC 29-79 (Cal. Labor Comm'r 1981), discussed in Julian, supra note 164, at 322-24.

175. Id. at 323 (quoting Wolf, No. TAC 29-79, at 11).

176. No. TAC 17 MP 114 (Cal. Labor Comm'r 1982), discussed in Singer, supra note 160, at 256-57.

177. Adam B. Nimoy \& Jackson D. Hamilton, Attorneys and the California Athlete Agencies 
the cited cases involved personal managers, these decisions articulate a view that could affect many entertainment attorneys. As a consequence of the Labor Commissioner's liberal construction of procurement in these cases, no attorney who negotiates einployment contracts on behalf of an artist-client can be entirely confident that such conduct is immune from regulation under the Act. Lawyers can be subject to onerous sanctions for engaging in the seemingly inculpable and traditionally legal act of negotiating an agreement between an artist and a purchaser of talent. These interpretations also discourage zealous representation of chents because certain aspects of the lawyer's traditional role have been proscribed.

While the courts and the Labor Commissioner have attempted to give substance to the term procurement in order to give fair warning to attorneys and personal managers, they have yet to cultivate clear and workable criteria for ascertaining whether an individual has engaged in unlawful procurement. In fact, a precise definition of procurement has proven quite elusive; the existing judicial and administrative interpretations have failed to clarify the concept sufficiently, and many personal representatives still guess at its meaning. Entertainment attorneys, like personal managers, are in an uncertain position under the Act: if they perform some of the tasks customarily associated with their profession, they run the risk of violating the law and being subject to potentially harsh penalties assessed by the Labor Cominissioner. Because of this inherent unfairness, an exemption for attorneys is warranted. ${ }^{178}$

\section{Ineffective Amendatory Clarification of Procurement}

The legislature attempted to delineate the concept of procurement more exphicitly when it amended the Act to exclude two specific procurement activities: "procuring, offering, or promising to procure recording contracts for an artist"179 and acting "in conjunction with, and at the request of, a hicensed talent agency in the negotiation of an employment contract."180 These modifications, however, do not remedy the ambigu-

Act: The Toll of the Bill, 7 Hastings CoMm. \& ENT. L.J. 551, 563 (1985) (citing Pryor and Fisher v. Shepard, No. AMC 7-78 MP 453 (Cal. Labor Comm'r 1981)).

178. This Comment does not advocate overturning the entire Act, or $\$ 1700.4$, because of this defect. And although an argument could be made that such a fundamental ambiguity warrants striking down the Act, the nltimate success or failure of such a contention is beyond the scope of this Comment. The essential purpose of this Comment is to alert attorneys in the entertainment industry to the potential hazards generated by the Act's proscriptions on their conduct. Furthermore, this Comment proceeds on the assumption that there is a need for some regulation of personal representatives in the entertainment industry, see Hearings, supra note 10, at 14 (comments of Marvin Faris), 28-29 (comments of Roger Davis), but that the Act's inferential regulation of attorney conduct is excessive and unjustified.

179. CAL. LAB. CODE $\S 1700.4$ (a) (West 1989).

180. Id. $\S 1700.44$ (d). The amendments to sections 1700.4 (a) and 1700.44 (d) were first added in 
ity inherent in the Act.

The first exemption is a step in the right direction because it recognizes that personal managers and attorneys, rather than talent agents, customarily negotiate recording contracts for their artist-clients. ${ }^{181}$ Under this exeinption, personal managers and attorneys can negotiate recording deals for their chents without complying with the strict licensure requirements of the Act. The express language of the exception, however, apphies only to recording contracts; negotiation of contracts for hve performances, merchandising, or concert tours, for example, are not exempt.

The second exeinption enables attorneys to coordmate employment deals for their artist-clients, provided they work "m conjunction with" and "at the request of" licensed talent agents. Thus, all engagements not exeinpted by the recording contract exception can be excused under this clause. As one commentator stated, this provision estabhishes the closest thing to a safe harbor for attorneys and personal managers. ${ }^{182}$ Unfortunately, the exclusion is effective only to the extent that licensed talent agents cooperate with unlicensed representatives. While some talent agents will validate the attorney's or inanager's lawful participation in a deal by providing a confirmation letter, the policy of many agencies is to refuse to issue such letters. ${ }^{183}$

Although they provide some solace to entertainment attorneys who are deeply involved with their chents' careers and engagement schedules, these exemptions are clearly insufficient. If attorneys represent artist-clients other than musicians or are unable to find talent agents willing to collaborate with them, they face precisely the same plight they confronted before the amendments. The amendinents simply shift the focus away from the real shortcoming of the Act-its failure to exempt attorneys from its operation, especially when they do no more than engage in conduct traditionally identified with the practice of law.

\section{An Alternative Mode of Enforcement: California's Legal-Ethics Rules}

Exemptimg attorneys from regulation under the Talent Agencies Act is warranted in hight of an attorney's duties and responsibilities under the

1982 and renewed in 1984. They expired, however, on January 1, 1986, by their own sunset provisions. Green \& Green, supra note 138, at 359. Then, on July 24, 1986, at the recommendation of the California Entertainment Commission, these exceptions became permanent additions to the Act. Id. at 359-60.

181. See Brindze, supra note 67, at 251.

182. See Jelin, supra note 122 , at 24.

183. Id. 
Professional Rules ${ }^{184}$ and the State Bar Act. ${ }^{185}$ First, the positive and negative duties imposed by the state's legal-ethics rules are sufficient to protect the interests of artists in the entertainment industry, at least to the extent that those interests are protected by the Act and, in some situations, to an even greater degree. Second, several provisions of the Act are redundant or conflict with the Professional Rules and the State Bar Act. Finally, even when the lawyer acts in a dual capacity (attorneymanager or attorney-agent), the artist is protected by legal-ethics rules that require attorneys to handle theinselves in accord with the ethical and legal constraints imposed on thein as attorneys. The sufficiency of the state's ethical rules, and the duplicative and contradictory nature of the Act's regulations in light of the those rules, justify exempting attorneys froin regulation under the Act.

\section{The Sufficiency of State Ethics Provisions to Police Attorney Procurement Activity ${ }^{186}$}

Although one commentator lias observed that "[d]iscussing ethical considerations in the entertainment field often invites sarcastic coinparisons to 'military intelligence,' 'bemign neglect,' 'jumbo shrimp' or otlier exainples of oxyinoromic wit," 187 the state's ethical rules and disciplinary authority constitute an imposing force in guiding attorney conduct. The Professional Rules and the State Bar Act govern almost every conceivable activity of the attorney practicing in California. The principal ain of the Professional Rules is threefold: to regulate the professional conduct of attorneys througl discipline; to protect the public; and to foster respect and confidence in the legal profession. ${ }^{188}$ Breach of an attorney's duties and responsibilities under these rules can result in temporary suspension from the bar or, in egregious cases, expulsion from the profession. ${ }^{189}$ These rules, with their positive and negative duties, undoubtedly

184. See Professional Rules, supra note 29, Rules 1-100 to 5-320.

185. CAL. Bus. \& Prof. Code $\S \S 6000-6228$ (West 1990 \& Supp. 1991).

186. It is important to reiterate that California's legal ethics rules are not modeled after the ABA Model Rules or Model Code. Equally important, however, is the notion that "[e]thics opinions and rules and standards promulgated by other jurisdictions and bar associations may ... be considered" in interpreting the duties and prohibitions mandated by the California Rules. Professional Rules, supra note 29, Rule 1-100(A).

187. Marks, supra note 69, at 483.

188. Professional RULes, supra note 29, Rule 1-100(A). The rule continues: "The prohibition of certain conduct in these rules is not exclusive. Members are also bound by applicable law including the State Bar Act and opinions of California courts." Id. (citation omitted).

189. The State Bar Act provides:

After a hearing for any of the causes set forth in the laws of the State of California warranting disbarnent, suspension or other discipline, the board has the power to recommend to the Supreme Court the disbarnent or suspension from practice of members or to discipline them by reproval, public or private, without such recommendation.

Cal. Bus. \& Prof. Code $\S 6078$ (West 1990). 
serve to protect artists from overreaching and unscrupulous practices by lawyers.

\section{a. Positive Duties}

The state's exhaustive legal-ethics provisions imvariably impose greater duties and obligations on attorneys than tlie Talent Agencies Act. For example, an attorney has a well-established fiduciary duty that an agent or personal manager does not have. ${ }^{190}$ The qualification requirements of the California State Bar are also more comprehensive than the Act's. In order to practice law in the State of California, an applicant must satisfy certain educational requisites, satisfy the extensive requireinents of a moral-character screening process, and pass a difficult bar examination. ${ }^{191}$ Under the Act, lowever, registrants need not fulfill any educational or testimg requirement-they need only file an application witlı tlie requisite fee and bond, accompamied by affidavits of two reputable residents attesting to tlie apphicant's good moral cliaracter. ${ }^{192}$

The Professional Rules and the State Bar Act provide additional express duties that the attorney must observe, most of which liave no analogue in the Talent Agencies Act. One of these duties is the attorney's obligation to maintain chient confidences. Section 6068(e) of the State Bar Act provides that the attorney is bound " $\mathrm{t}] \mathrm{o}$ maintain inviolate the confidence, and at every peril to himself or herself to preserve the secrets, of liis or lier client."193

In addition, attorneys must regularly inform clients of actions taken on their belialf and must make timely replies to a client's requests for information. ${ }^{194}$ The lawyer is under an affirmative duty to respond to

190. See Cole-Wallen, supra note 4 , at $491-92$ \& n.60. The author discusses Croce v. Kurnit, 565 F. Supp. 884 (S.D.N.Y. 1982), aff'd in part, 737 F.2d 229 (2d Cir. 1984), where the court dismissed fiduciary charges against two personal managers in the absence of fraud or gross unfaimess, but held that an attorney owed a higher fiduciary duty to his clients. See Cole-Wallen, supra note 4, at 491 n.60. The court explained:

Even in the absence of an express attorney-client relationship, however, a lawyer may owe a fiduciary obligation to any persons with whom he deals. In particular, a fiduciary duty arises when a lawyer deals with persons who, although not strictly his clients, he has or should have reason to believe and [sic] rely on him.

Croce, 565 F. Supp. at 890 (citations omitted); see also Lloyd Z. Remick \& David S. Eisen, The Personal Manager in the Entertainment and Sports Industries, 3 U. M1AMI ENT. \& SPORTS L. REV. 57, 84 (1986) (citing as one of the Act's shortcomings its failure to incorporate a fiduciary duty into its scheme); Greenberg, supra note 125, at $862 \mathrm{n} .135$ ("The nature of the fiduciary relationship is one in which one party depends or relies upon another to satisfy certain needs . . .." (citing Tamar Frankel, Fiduciary Law, 71 CALIF. L. REv. 795 (1983))).

191. Cal. Bus. \& Prof. Code $\S 6060$ (West 1990) (qualifications for admission to California Bar).

192. CAL. LAB. CODE $\S 1700.6$ (West 1989) (application procedure for licensure under the Act); see supra text accompanying notes 93-95.

193. Cal. Bus. \& Prof. Code $\S 6068(e)$ (West 1990).

194. CAL. Bus. \& PROF. CODE $\S 6068(\mathrm{~m})$ (West 1990) (attorney bound to "respond promptly to reasonable status inquiries of clients and to keep clients reasonably informed of significant 
such inquiries if they are part and parcel of the services being rendered to an artist-client. Under the Talent Agencies Act, which imposes no such duty on the talent agent, the hicensed individual can evade the inquiries of persistent artists wondering where and when their next jobs 1might be.

\section{b. Negative Duties}

The proscriptions the ethical rules place on attorney conduct are perhaps more significant than the positive duties attorneys owe to their artist-chents. First, an attorney must avoid conflicts of interest. The Professional Rules contemplate two types of conflicts: those created by representing interests and parties adverse to the chents', ${ }^{195}$ and those created when attorneys enter business transactions with their chents or acquire a financial interest adverse to their chents. ${ }^{196}$

Conflicts of the first type arise frequently in the entertainment industry because the relationships involved in most transactions are coinplex and because entertainment attorneys often counsel multiple parties who can have antagomistic interests. ${ }^{197}$ A lawyer might represent multiple menbers of a single rock band, for example, or a notion picture producer in one transaction and an artist $\mathrm{m}$ a related transaction with that same producer. In either case, the attorney is required before participating in the deal to obtain the informed written consent of each affected chent and to disclose any actual or reasonably foreseeable adverse effects that might be generated by the conflict. ${ }^{198}$ The Talent Agencies Act, by contrast, contains no comparable standard, and the potential for selfdealing by talent agents is enhanced. For example, an opportunity for self-dealing may exist when a talent agent has more than one artist on the roster who qualifies for a particular job. Depending upon the relative earning potential of each artist, the agent may represent the more highly compensated artist with greater enthusiasin, banking on a greater return if that artist is eventually hired. The less profitable artist, in this case, is deprived of fair representation by his agent, and the Act contains no safeguards against such self-dealing.

Second, the Professional Rules prohibit attorneys from entering

developments in matters with regard to which the attorney has agreed to provide legal services"); Professional Rules, supra note 29, Rule 3-500 (attorney must "keep a client reasonably informed about significant developments relating to the employment or representation and promptly comply with reasonable requests for information").

195. See Professional Rules, supra note 29, Rule 3-310(A) to (D) (prohibiting attorneys from representing clients with conflicting interests or accepting employment adverse to their client).

196. Id. Rule 3-300 (establishing guidelines for business transactions between attorneys and clients).

197. See Leonard M. Marks, Entertainment Law Is Rife with Conflicts of Interest: California Targets Attorneys' Ethics, BILlBOARD, June 24, 1989, at 9 (discussing various situations which create conflicts of iuterest for the entertainment lawyer).

198. Professional Rules, supra note 29, Rule 3-310(A) to (D). 
business relationships with, or acquiring business interests adverse to, their clients' unless the terms are fair, reasonable, and fully disclosed to the clients in a writing that the artist can understand. ${ }^{199}$ Attorneys inust also advise clients in writing that they inay seek independent legal counsel regarding the deal, and chents inust consent in writing to the terms of the transaction. ${ }^{200}$ Examples of business transactions that inight fall under this rule include: (1) entermg a partnership witl the artist; (2) becoming an officer of the artist's loan-out corporation; or (3) agreeing to becoine the artist's personal inanager or agent. No corresponding requirement exists under the Talent Agencies Act.

The Professional Rules also protect artists by prohibiting attorneys from executing their duties and functions incompetently. ${ }^{201}$ This rule suggests that attorneys witl no previous experience in the industry who represent artists in coinplex entertamment negotiations or transactions witliout consulting a sufficiently knowledgeable attorney can be acting improperly. ${ }^{202}$ The Act does not offer this protection; that is, the Act in no way deters incompetent behavior by hicensed individuals.

Attorneys in Califormia are also enjoined froin coinmitting any act involving "moral turpitude," corruption, or dislonesty, whetlier accoinplished in the course of their duties as attorneys or otlerwise. ${ }^{203}$ Proscribed acts include intentional or unintentional inisstateinent of information, misrepresentation, breacl of trust, breacl of fiduciary duty, failure to account, fraud, deceit, misappropriation or comıningling of funds, and einbezzlement. Other provisions of the Professional Rules and the State Bar Act limit attorney advertising and publicity, ${ }^{204}$ solicitation of clients, ${ }^{205}$ and compensation. ${ }^{206}$ Breach of these rules can be grounds for suspension or disbarment even when no criminal or civil penalty attaches. ${ }^{207}$ Sucli severe professional penalties create powerful

199. Id. Rule 3-300(A).

200. Id. Rule 3-300(B), (C).

201. Rule 3-110 provides in part: "(A) A member shall not intentionally, or with reckless disregard, or repeatedly fail to perform legal services competently. (B) To perform legal services competently means diligently to apply the learning and skill necessary to perform the member's duties arising from employment or representation." Id. Rule 3-110.

202. Rule 3-110(B) continues: "If the inember does not have sufficient learning and skills ... the member may nonetheless perform such duties competently by associating or . . professionally consulting another member reasonably believed to be competent . . ." Id. Rule 3-110(B).

203. Cal. Bus. \& Prof. CODE $\S 6106$ (West 1990) (commission of act involving moral turpitude, dishonesty, or corruption is cause for disbarment or suspension).

204. See Professional Rules, supra note 29, Rule 1-400 (rules governing advertising and solicitation).

205. See Cal. Bus. \& Prof. Code $§ 6152$ (West 1990) (prohibits solieitation); Professional RULES, supra note 29, Rule 1-400.

206. See Professional Rules, supra note 29, Rule 4200(A) (fee must not be illegal or unconscionable).

207. Cal. Bus. \& Prof. Code $\S 6101$ (West 1990). 
disincentives for attorneys tempted to deal unscrupulously with their artist-clients and provide more stringent protection for artists than the Act.

\section{Redundant and Contradictory Nature of the Act's Provisions in Light of California's Legal-Ethics Rules}

The surety bond requirement of section 1700.15 of the Talent Agencies Act is one illustration of the Act's redundancy in hight of the ethical rules controlling lawyers. ${ }^{208}$ The $\$ 10,000$ bond requirement of the Act is duphicative because the California Bar administers the Client Security Fund (CSF) to compensate clients who have suffered "pecumary losses caused by the dishonest conduct of . . . members of the State Bar."209 And an injured chent's recovery from the security fund does not affect that person's right to institute an action against the lawyer individually or his firm. ${ }^{210}$ While the bond requirement arguably offers more direct protection to the artist than the CSF alone, this contention loses much of its vitality when one realizes that most lawyers also carry professional liability imsurance in amounts sufficient to protect their clients. ${ }^{211}$ Moreover, the wisdom behind the bond requirement can be challenged even as applied to nonattorney agents because the amount of the bond can be trivial in comparison to the compensation paid to many artists. ${ }^{212}$

The trust-fund requirement of section 1700.25 of the Act is also repetitive because the Professional Rules require an attorney to deposit funds collected on belialf of the artist in a separate trust fund ${ }^{213}$ and to maintain records and promptly disburse funds to the client. ${ }^{214}$ Violations of these rules often result im disciplinary action against the attorney. ${ }^{215}$ The Professional Rules include additional proscriptions against commingling of funds, requiring the attorney to notify the client of the receipt of funds and demanding that-absent written permission from the client to the contrary-the trust fund be maintained in the State of California. ${ }^{216}$ In sliort, these ethical standards offer at least as much pro-

208. See Nimoy \& Hamilton, supra note 177 , at $567-68$ (discussing redundancy of bond requirement with respect to Athlete Agencies Act, CAL. LAB. CoDE $\$ \S 1500-1547$ (West 1989)).

209. Cal. Bus. \& Prof. Code $§ 6140.5$ (a) (West 1990).

210. Marks, supra note 69 , at 500 .

211. Nimoy \& Hamilton, supra note 177 , at 567 .

212. Id.

213. Professional Rules, supra note 29, Rule 4-100 (requiring attorney to preserve identity of funds and property of client).

214. Compare CAL. LAB. Code $\S 1700.25$ (West 1989) (requiring disbursement within 15 days) with Professional Rules, supra note 29, Rule 4-100(B)(4) (requiring disbursement to occur "promptly").

215. Nimoy \& Hamilton, supra note 177 , at $568-69$ (citing Rogers v. State Bar, 620 P.2d 1030 (Cal. 1980)).

216. Professional Rules, supta note 29, Rule 4-100(A). 
tection to the artist as the Act, and the Act's proscriptions as applied to attorneys would simply constitute unnecessary duplication.

The Act's fee requirements are also redundant. The Act's regulation of fees is himited to a requirement that talent agents file fee schedules $^{217}$ and the Comnnissioner's discretionary authority to set an unofficial limit on fees. ${ }^{218}$ By contrast, the Professional Rules declare that an attorney "shall not enter into an agreement for, charge, or collect an illegal or unconscionable fee"219 and set forth numerous criteria for determining whether a fee is reasonable. ${ }^{220}$ Thus, "[t]he astute artist who recognizes that an attorney is subject to standards of reasonableness with respect to fee setting might engage an attorney to perform services which otherwise would be provided by other personal representatives."221

Those provisions of the Act that directly conflict with California's legal-ethics rules are as troublesome as its redundant provisions. One conflict imperils the attorney-chent privilege. Under section 1700.27 , the talent agent must inake all records and books available to the Labor Commissioner for inspection upon request; ${ }^{222}$ those records inay contain "[a]ny ... information which the Labor Commissioner requires."223 Pursuant to section 6068(e) of the State Bar Act, however, attorneys are coininanded to sustam client confidences and safeguard secrets, notwithstanding any threat to themselves. ${ }^{224}$ While this conflict might seem illusory because the documents would ordmarily be sought only in a dispute involving the artist against the attorney-a situation in which the privilege does not apply - there are instances in which the Labor Commissioner can seek the records for other purposes, such as to police fee requirements and other regulations of the Act. In such cases, where the Act's disclosure requirement conflicts with the attorney's strict duty of confidentiality, the attorney-chent privilege is imperiled.

A final, yet ininor, incongruity derives from the restriction contained in section 1700.35 of the Act, which prohibits talent agents from knowingly permitting persons of "bad character" to frequent the agency. ${ }^{225}$ This provision interferes with the attorney's express right and moral obligation to represent such individuals by effectively barring them from the lawyer's offices.

217. See Cal. LaB. CODE $\S 1700.24$ (West 1989).

218. The Talent Agencies Act contains no express provision regulating the amount of fees an agent may charge. Talent agents' fees are governed more directly by guild and union fee ceilings. See supra text accompanying note 44.

219. Professional RULES, supra note 29, Rule 4-200(A).

220. Id. Rule 4-200(B).

221. Cole-Wallen, supra note 4 , at 523.

222. CAL. LAB. CODE $\S 1700.27$ (West 1989).

223. Id. $\S 1700.26(4)$.

224. Cal. Bus. \& Prof. Code $\S 6068(e)$ (West 1990).

225. CAL. LAB. CODE $\S 1700.35$ (West 1989). 


\section{Applicability of Legal-Ethics Rules to Attorneys Engaged in Dual Occupation}

California's ethics rules apply even where the attorney engages in a dual occupation, serving either as the artist's attoruey-manager or attorney-agent. ${ }^{226}$ While no ethics rule in California forbids an attorney froin engaging simultaneously in another discipline or endeavor, an attorney " 'remains bound at all times by the ethical rules which govern his activities qua attorney." "227 The attorney's relationship with his or her chents remains that of a fiduciary in connection with any secondary occupation even where the affiliation between others engaged in that activity and their clients does not contemplate a fiduciary duty. ${ }^{228}$ The attoruey is bound by rules of legal ethics even where the secondary occupation includes legal tasks that inay be performed by a layman. ${ }^{229}$ One coinmentator described this phenomenon as follows:

If a lawyer provides extralegal services and enters into business or investinent deals with a chent, legal ethics deinand that he always conduct himself as a lawyer. A lawyer cannot ethically switch hats. He cannot ethically operate his law practice and a ... management company as nominally distinct businesses; he cannot ethically engage in extralegal activities to feed his law practice. If the lawyer offers extralegal services, ethics of his profession deinand that he always handle himself in accord with the ethical and legal constraints imposed on him as a licensed attorney-at-law. 230

In sum, when attorueys inadvertently engage in extralegal activities or purposely don two hats, they are required to abide by the state's rules of legal ethics. These rules cover the entire range of legal functions and penalize inost categories of attorney misconduct. The standards, geared specifically to the professional behavior of lawyers, are strict, extensive, and well established. Because the ethics rules protect artists to the same degree as the Talent Agencies Act and in soine instances surpass the Act's protection, attorneys should be exempt froin the Act's regulatory regime. ${ }^{231}$

226. See BASKERVILLE, supra note 6, at 162-63.

227. Jim Melanson, Attomey/Manager Combo Under Fire, BillboARd, Dec. 27, 1975, at 1, 12 (quoting 1935 opinion issued by Los Angeles County Bar Association).

228. Formal Op. 328, supra note 77 , at 65 .

229. Id. ("In every case where a lawyer performs services for a client which could be performed by one not a member of the bar, nevertheless, in performing them in the course of his legal services he is acting as a lawyer" and is bound by principles of legal ethics (quoting ABA Comn. on Ethics and Professional Responsibility, Formal Op. 272 (1946).).

230. BASKerVILlE, supra note 6, at 162-63.

231. One may argue that the Act's proscriptions are a good supplement to the state's ethics rules and provide the aggrieved artist with an avenue of relief that is specifically tailored to their problem. This argument is not without force. However, it simply ignores the obvious sufficiency and stringency of the state's legal ethics rules to police attorney conduct in the entertainment industry, and the sentiment of legislators that that Act's proscriptions, if applied to attorneys, would 


\section{IV}

\section{Alternatives to EXPRESSLY EXEMPTING ATtorneys FROM THE TALENT AgENCIES ACT}

\section{A. Imposing a Registration Requirement on Attorneys}

As an alternative to an express exemption, the California Legislature should consider amending the Act to require only registration-as opposed to licensure-of attorneys. This would, at the very least, relieve the attorney of the burden of depositing a surety bond. The registration requirement would also eliminate the conflicts that currently exist between the Act and California's legal-ethics code. ${ }^{232}$ Furthermore, attorneys would be free to engage in negotiating contracts-one of the functions for which the entertainment lawyer is best suited-without facing excessive restrictions.

Registering attorneys would also free the Labor Commissioner from unnecessary administrative burdens. By inaintaining a directory of attorneys engaged in procurement activity, the Commissioner could selectively momitor their activities to detect improprieties. Moreover, the Labor Commissioner could assign a smgle staff member to supervise attorneys, freeing other staff members to concentrate on more immediate threats to artists.

\section{B. Reassessing the "Incidental Booking" Option}

Notwithstanding lostile reactions to the recommendation in the past, the legislature should reconsider an "incidental booking" exception-this time specifically tailored to exclude lawyers from the Act when procurement activity is not their primary function. Sucli an exception would further clarify the intended scope of the Act and would eliminate the unreasonable restrictions that currently face lawyers who occasionally seek employment for their artist-chents. Members of the California Bar who represent athletes enjoy an analogous exception under the Califorma Atlilete Agents Act. ${ }^{233}$ The exemption in that statute demonstrates the legislature's recognition that the licensure provisions are duphicative because attorneys are already lield to stricter standards than nonattorney athlete agents. ${ }^{234}$ The Talent Agencies Act's lack of a similar exception is illogical: there is no expressed reason to

be unnecessarily duplicative. See, e.g., Hearings, supra note 10, at 45 (comments of Roger Davis) (arguing that duplicate regulations are not necessary under any circumstances).

232. See supra notes $222-25$ and accompanying text.

233. CAL. LAB. Code $\S 1500(b)$ (West 1990) (“'Athlete agent' does not include . . . any member of the State Bar of California when acting as legal counsel for any person.").

234. Jelin, supra note 122, at 24 (stating that the "reasoning behind the expressed exemption for attorneys as sports managers" is that attorneys have alrcady been "scrutinized" by the state bar); Cole-Wallen, supra note 4, at 529 (confirming that exception acknowledges higher fiduciary duty imposed on attorneys). 
differentiate between attorneys who procure employment for artists and those who procure for athletes.

An incidental-booking exception to the Act must, of course, be drafted in a realistic and pragmatic manner to appease naysayers who regard such exceptions as vague and unworkable. New York currently has an exception that applies to "mcidental" booking performed by managers. Section 171 of New York's General Business Law provides: " 'Theatrical einployment agency' ... does not mclude the business of managing such entertainments, exhibitions or performances, or the artists or attractions constituting the same, where such business only incidentally involves the seeking of employment therefor."235 Echomg New York's example, Califorma should consider adding language to the following effect to section 1700.4(a) of the Act:

"Talent agency" means a person or corporation who engages in the occupation of procuring, offering, promising, or attempting to procure employment or engagements for an artist or artists, except (1) that the activities of procuring, offering, or promising to procure recording contracts for an artist or artists shall not of itself subject a person or corporation to regulation and hicensing under this chapter; and (2) that an attorney duly licensed to practice law in the State of California shall not be subject to regulation and licensing under this chapter (a) when the attorney is acting primarily as legal counsel for the artist or artists, or (b) when the attorney's representation only incidentally involves the seeking of employment or results in employment for the artist or artists. ${ }^{236}$

New York has experienced no major problems with its incidental-booking exception-which is even broader than the proposed language above-nor has the entertainment mdustry in New York fallen apart as a result. $^{237}$ In fact, only a handful of cases $\mathrm{m}$ New York have arisen under the exception, owing probably to the New York judiciary's strict application of this safe harbor. ${ }^{238}$ New York has handled the issue in a sensible manner, recognizing that attorneys with many years of experience in the business who are intimately involved in their chents' work necessarily engage theinselves in soine way in the employment aspects of their chents' careers. Califorma should acknowledge these entertaininent-industry realities, and the lawyer's role therein, and follow suit.

235. N.Y. GeN. Bus. Law $\S 171(8)$ (McKinney Supp. 1991) (emphasis added).

236. CAL. LAB. CoDE $\S 1700.4$ (West 1989) (language in italics denotes proposed change).

237. Hearings, supra note 10, at 144 (comments of Howard L. Thaler).

238. See, eg., Pine v. Laine, 321 N.Y.S.2d 303 (App. Div. 1971) (holding that an individual who was not licensed as a theatrical employment agency was not entitled to recover from an artist for services in arranging recording contract for that artist unless he was the artist's personal manager and the seeking of employment was only mcidental to the business of management); Friedkin v. Harry Walker, Inc., 395 N.Y.S.2d 611 (Civ. Ct. 1977) (holding that an agent who procured lectures for a client who was a motion picture director was required to acquire an employment-agency license where the agent was not in the business of managing the client and the seeking of employment was not only incidentally involved). 


\section{CONCLUSION}

Attorneys figure prominently in the entertainment industry; they serve diverse functions and represent many types of clients. When representing artists, however, they must be mindful of California's Talent Agencies Act because the Act's proscriptions have been interpreted to include functions, such as contract negotiation, traditionally performed by lawyers.

The Act's legislative history, its ambiguous language, and California's legal-ethics rules governing attorney conduct render regulation of attorney behavior under the Act unfair, unnecessary, and redundant, and warrant an express exemption for attorneys. Attorney conduct should not be subject to scrutiny under the Act because the Act, as initially conceived by its drafters and as understood by those involved in the legislative process, was never intended to apply to the activities of attorneys. Because current translations have abandoned the Act's original design by purporting to regulate attorney conduct, the Act can ambush individuals already subject to rigorous behavioral restrictions and harsh penalties for their breach. In addition, the Act's ambiguous language-in particular, its failure to define the operative term "procurement"-and the Labor Commission's inability to formulate a coherent and consistent definition unfairly expose attorneys to the Act's severe penalties when they engage in endeavors custornarily performed by lawyers. Exemption is also justified because the Professional Rules and the State Bar Act are clearly sufficient to secure the ends of the Talent Agencies Act with respect to attorney conduct. Indeed, in some instances the state's legalethics code provides greater protection to artists against overreaching or improper activity by attorneys. Moreover, because the Act's provisions are not designed specifically to regulate lawyers, they frequently duplicate and occasionally contradict rules governing the ethical obligations of attorneys.

The legislature should consider two proposals either in addition to, or as an alternative to, an express exemption of attorneys from the Act: a registration requirement or an imcidental-booking exception. A registration requirement could have the dual effect of alleviating some of the Labor Commission's admimistrative burdens with respect to enforcement of the Act and enabling attorneys to render their much-needed services to artists without fear of reprisal under the Act. An artfully drafted incidental-booking exception could permit attorneys to counsel their artistchents even if the lawyer's legal services incidentally resulted in employment for the artist.

If no change is forthcoming, the position of attorneys in California's entertainment industry, insofar as they represent artists, remains uncertain. Attorneys must constantly beware of a statutory regime without 
knowing whether it actually applies to their conduct. Alternatively, attorneys can simply choose to ignore the Act's proscriptions, factoring the possibility of artist dissatisfaction into their decisions regarding representation of clients. To alleviate these problems and to improve the Act, the California Legislature should consider the proposals set forth im this Comment. 
